OPEN ACCESS

Edited by:

Yajun Wang,

Sichuan University, China

Reviewed by:

Takeshi Ohkubo,

Ibaraki University, Japan

Hai Lin,

Shandong Agricultural University,

China

${ }^{*}$ Correspondence:

Grégoy Y. Bédécarrats

gbedecar@uoguelph.ca

Specialty section:

This article was submitted to

Avian Physiology,

a section of the journal

Frontiers in Physiology

Received: 14 February 2020

Accepted: 29 May 2020

Published: 26 June 2020

Citation:

Hanlon C, Ramachandran R,

Zuidhof MJ and Bédécarrats GY (2020) Should I Lay or Should I Grow: Photoperiodic Versus Metabolic Cues in Chickens. Front. Physiol. 11:707.

doi: 10.3389/fphys.2020.00707

\section{Should I Lay or Should I Grow: Photoperiodic Versus Metabolic Cues in Chickens}

\author{
Charlene Hanlon', Ramesh Ramachandran², Martin J. Zuidhof ${ }^{3}$ and \\ Grégoy Y. Bédécarrats ${ }^{1 *}$
}

\begin{abstract}
'Department of Animal Biosciences, University of Guelph, Guelph, ON, Canada, ${ }^{2}$ Center for Reproductive Biology and Health, Department of Animal Science, Pennsylvania State University, University Park, PA, United States, ${ }^{3}$ Department of Agricultural, Food and Nutritional Science, University of Alberta, Edmonton, AB, Canada
\end{abstract}

While photoperiod has been generally accepted as the primary if not the exclusive cue to stimulate reproduction in photoperiodic breeders such as the laying hen, current knowledge suggests that metabolism, and/or body composition can also play an influential role to control the hypothalamic-pituitary gonadal (HPG)-axis. This review thus intends to first describe how photoperiodic and metabolic cues can impact the HPG axis, then explore and propose potential common pathways and mechanisms through which both cues could be integrated. Photostimulation refers to a perceived increase in day-length resulting in the stimulation of the HPG. While photoreceptors are present in the retina of the eye and the pineal gland, it is the deep brain photoreceptors (DBPs) located in the hypothalamus that have been identified as the potential mediators of photostimulation, including melanopsin (OPN4), neuropsin (OPN5), and vertebrateancient opsin (VA-Opsin). Here, we present the current state of knowledge surrounding these DBPs, along with their individual and relative importance and, their possible downstream mechanisms of action to initiate the activation of the HPG axis. On the metabolic side, specific attention is placed on the hypothalamic integration of appetite control with the stimulatory (Gonadotropin Releasing Hormone; $\mathrm{GnRH}$ ) and inhibitory (Gonadotropin Inhibitory Hormone; GnlH) neuropeptides involved in the control of the HPG axis. Specifically, the impact of orexigenic peptides agouti-related peptide (AgRP), and neuropeptide $Y$ (NPY), as well as the anorexigenic peptides pro-opiomelanocortin (POMC), and cocaine-and amphetamine regulated transcript (CART) is reviewed. Furthermore, beyond hypothalamic control, several metabolic factors involved in the control of body weight and composition are also presented as possible modulators of reproduction at all three levels of the HPG axis. These include peroxisome proliferatoractivated receptor gamma (PPAR- $\gamma$ ) for its impact in liver metabolism during the switch from growth to reproduction, adiponectin as a potential modulator of ovarian development and follicular maturation, as well as growth hormone (GH), and leptin (LEP).

\footnotetext{
Keywords: sexual maturation, laying hen, metabolism, photoreception, HPG axis
} 


\section{INTRODUCTION}

Decades of genetic selection along with significant improvements in environmental conditions and nutrition have allowed modern commercial chickens to become exceedingly efficient. However, as traits associated with growth and reproduction are negatively correlated (Siegel and Dunnington, 2017), divergent breeding objectives have been established for broiler and layer chickens. While breeding programs for layers have been instrumental in improving production by advancing sexual maturation, reducing the time of egg formation and improving peak of lay, limited emphasis was put on the underlying physiological processes, thus pushing the boundaries closer to the hen's biological limit (van Sambeek, 2010). With the rising demand for sustainable egg production, breeding companies have more recently focused on extending the laying period to achieve 500 eggs per hen at 100 weeks of age (van Sambeek, 2010; Bain et al., 2016). Physiologically, this will require precise co-ordination of several systems involved not only in the control of the reproductive axis, but also metabolism and nutrient partitioning. However, to date, most research models describing the control of the hypothalamic-pituitary gonadal (HPG) axis have largely focused on the impact of environmental cues such as photoperiod (Bédécarrats, 2015), rather than incorporating the impact of growth and metabolic status. Recent evidence suggests that modern commercial laying hens do not exclusively rely on photostimulation to initiate sexual maturation, as egg production may commence at an earlier age, prior to an increase in photoperiod (Baxter and Bédécarrats, 2019).

Conversely, broiler chickens have been intensively selected for increased growth rate and feed efficiency (Zuidhof et al., 2014).

Abbreviations: $\alpha$-MSH, Alpha-Melanocyte Stimulating Hormone; $\beta$-MSH, BetaMelanocyte Stimulating Hormone; $\gamma$-MSH, Gamma-Melanocyte Stimulating Hormone; ACTH, Adrenocorticotropin Hormone; AdipoR1, Adiponectin Receptor 1; AdipoR2, Adiponectin Receptor 2; AFE, Age of First Egg; AgRP, Agouti-related Peptide; ARC, Arcuate Nucleus; AVT, Arginine Vasotocin; CART, Cocaine and amphetamine-regulated transcript; CORT, Corticosteroid; CYP19A1, Cytochrome $\mathrm{P}_{450}$ aromatase; DA, Dopamine; DBP, Deep-Brain Photoreceptor; DIO2, Type 2 Deiodinase enzyme; DIO3, Type 3 Deiodinase; $E_{2}$, Estradiol; ER- $\beta$, Estrogen Receptor Beta; FSH, Follicle-Stimulating Hormone; GH, Growth Hormone; GH-R, Growth Hormone Receptor; GHRH, Growth Hormone-releasing hormone; GnIH, Gonadotropin-Inhibiting Hormone; GnIH-R, Gonadotropin-Inhibiting Hormone Receptor; GnRH-I, GonadotropinReleasing Hormone I; GnRH-II, Gonadotropin-Releasing Hormone II; GnRH-RI, Gonadotropin-Releasing Hormone Receptor I; GnRH-RIII, GonadotropinReleasing Hormone Receptor III; HPA axis, Hypothalamic-Pituitary Adrenal axis; HPG Axis, Hypothalamic-Pituitary Gonadal Axis; IGF-1, Insulin-like Growth Factor 1; IN, Infundibular Nucleus; INSR, Insulin Receptor; LD, Long Day; LEP, Leptin; LEPR, Leptin Receptor; LH, Luteinizing Hormone; LSO, Lateral Septal Region; MBH, Medial-Basal Hypothalamus; MC1R, Melanocortin Receptor subtype 1; MC3R, Melanocortin Receptor subtype 3; MC4R, Melanocortin Receptor subtype 4; MC5R, Melanocortin Receptor subtype 5; ME, Median Eminence; MEL, Melatonin; MRAP, Melanocortin Receptor Accessory Proteins; NPY, Neuropeptide Y; OPN1, Opsin 1; OPN3, Opsin 3; OPN4, Melanopsin (Opsin 4); OPN5, Neuropsin (Opsin 5); $\mathrm{P}_{4}$, Progesterone; PMM, Premammillary Nucleus; POMC, Pro-opiomelanocortin; PPAR- $\gamma$, Peroxisome Proliferator-activated Receptor Gamma; PRL, Prolactin; PT, Pars Tuberalis; PVN, Paraventricular Nucleus; PVO, Paraventricular Organ; RGR, Retinal G-coupled Receptors; SD, Short Day; StAR, Steroidogenic Acute Regulatory Protein; $\mathrm{T}_{3}$, Triiodothyronine; $\mathrm{T}_{4}$, Thyroxine; TMTs, Teleost Multiple Tissue Opsins; TSH, Thyroid-Stimulating Hormone; VA-Opsin, Vertebrate-Ancient Opsin; VIP, Vasoactive Intestinal Peptide.
As a result, broiler breeders, the parent stock of broilers, carry the genetics for rapid growth, while displaying poor reproductive capacity in comparison to layers. Specifically, when fed adlibitum, breeders tend to rapidly become overweight due to a lack of appetite control. In turn, this results in compromised health, along with impaired reproduction. Thus, pullets are typically reared under feed restriction programs (Decuypere et al., 2010). Although the impact of body weight on reproductive fitness has been studied in broiler breeders (Eitan et al., 2014; van der Klein et al., 2018) and migratory birds (Davies and Deviche, 2014), this aspect has been largely overlooked in laying hens. While it is accepted that laying hens need to achieve a mature body weight prior to sexual maturation (Brody et al., 1984; Dunnington and Siegel, 1984; Zelenka et al., 1987), little is known about the physiological conditions and body composition underlying this suggested threshold.

As more evidence of convergence between hormones influencing both metabolic control and reproductive processes emerges, it is imperative to further study and describe these interactions. Thus, this review aims to summarize the current knowledge on the control of sexual maturation in chickens, with a specific emphasis on the integration of photoperiodic cues while presenting evidence of possible interactions with factors involved in metabolic control.

\section{PHOTOPERIODIC CONTROL OF REPRODUCTION}

\section{Overview of the Effects of Photoperiod on the Reproductive Axis}

Early studies conducted in wild birds showed that increased day length during spring coincided with increases in gonadal weight and size (Homma et al., 1994) and the initiation of reproduction and breeding (Whetham, 1933; Byerly and Moore, 1941; Sharp, 1993). This concept of reproductive modifications in response to changing seasonal day length served as starting point for the development of lighting programs under managed environments. Since then, the integration of photoperiodic signals on the activation and function of the HPG axis has been fairly well characterized and reviewed elsewhere (Sharp, 2005; Bédécarrats et al., 2009; Bédécarrats, 2015; Bedecarrats et al., 2016). This axis is primarily responsible for providing a cohesive signal, through the coordinated synthesis and secretion of hormones to effectively initiate or terminate the reproductive cycle. The hypothalamus, which acts as a neuroendocrine control center, is responsible for secreting stimulatory neuropeptides, gonadotropin-releasing hormones (GnRH-I and GnRH-II), along with an inhibitory neuropeptide, gonadotropin-inhibitory hormone (GnIH; Matsuo et al., 1971; Tsutsui et al., 2000). In turn, these neuropeptides regulate the synthesis and release of gonadotropins which then lead to the activation of the ovary, allowing for the initiation of lay. In vertebrates, light, hence photoperiod, is detected by photoreceptors and transduced into nervous and endocrine signals (Ebrey and Koutalos, 2001). In avian species, these photoreceptors are present in the eye as 
visual photoreceptors on the retina, as well as in the pineal gland and the hypothalamus, as extra-retinal photoreceptors (Kumar et al., 2004) to coordinate photoperiodic responses.

Although the role of the pineal gland and its associated melatonin (MEL) production has not been directly linked to the ability of the photoperiodic response to trigger reproduction (Juss et al., 1993; Bentley et al., 2013; Kang and Kuenzel, 2015), MEL released by the pineal gland and the retina during the scotophase stimulates the expression of $\mathrm{GnIH}$ by the hypothalamus (Ubuka et al., 2005). During the pullet growing stage, when the chicken is sexually immature, photoperiod is maintained below $10 \mathrm{~h}$ of light, resulting in elevated levels of MEL, thus maintaining inhibition via GnIH. In addition to directly supressing GnRH production (Bentley et al., 2003, 2008) and release (Tsutsui et al., 2000), GnIH also supresses the hormonal response from the anterior pituitary by binding to its gonadotropin-inhibitory hormone receptor (GnIH-R) and preventing the secretion of gonadotropins, luteinizing hormone (LH), and follicle-stimulating hormone (FSH; Ciccone et al., 2004; Ikemoto and Park, 2005; Ubuka et al., 2006). At the time of photostimulation, reduced scotophase results in lower MEL synthesis, thus lifting the inhibition on the HPG axis by GnIH (Ikemoto and Park, 2005; Maddineni et al., 2008). Suppression of MEL production occurs through the stimulation of the pineal gland specific photoreceptor, pinopsin (Okano et al., 1994; Holthues et al., 2005). The resulting down-regulation of $\mathrm{GnIH}$ removes the suppression of $\mathrm{GnRH}$ and gonadotropes, allowing the pituitary to synthesize and release LH and FSH (Ikemoto and Park, 2005). Upon photostimulation, a longer day length will not only reduce the production of MEL, but also stimulate deep brain photoreceptors (DBPs) to trigger a greater synthesis and release of GnRH from the hypothalamus. Although two different isoforms of chicken GnRH have been characterized, GnRH-I and GnRH-II, which both bind to the GnRH receptors (cGnRHRI and cGnRH-RIII), it is now well accepted that GnRH-I is the neuropeptide released in the median eminence (ME) to stimulate pituitary gonadotropes by binding to cGnRH-RIII, the predominant receptor present in the pituitary gland (Shimizu and Bedecarrats, 2006; Joseph et al., 2009). Interestingly, it was shown that the pituitary ratio of GnIH-R to cGnRH-RIII switches at the time of sexual maturation (Shimizu and Bédécarrats, 2010), thus also shifting the sensitivity of the pituitary from inhibitory to stimulatory.

As GnRH increases, circulating levels of $\mathrm{LH}$ and FSH increase (Etches, 1996). Both glycoproteins are composed of 2 subunits including a common alpha subunit, along with a unique beta subunit responsible for their specific actions (Burke et al., 1979). While the major role of $\mathrm{LH}$ is the induction of ovulation through an increase in progesterone and testosterone production by the ovary of the mature hen (Shahabi et al., 1975), during the earlier stages of sexual maturation and follicular development, LH stimulates steroidogenesis of various sex hormones, such as androgens, estrogens, and progestins by the follicles and ovarian cortex (Robinson et al., 1988, 2003). On the other hand, the primary role of FSH during the follicular maturation process includes granulosa cell differentiation and the stimulation of steroidogenesis, as the pre-hierarchal follicles acquire FSH responsiveness (Johnson and Bridgham, 2001; Johnson and Woods, 2009a). In culture, administration of FSH demonstrated an increase in the production of cAMP in the smaller preovulatory follicles, while this effect of FSH was reduced as these follicles increase in size and become responsive to LH (Calvo and Bahr, 1983). Meanwhile, daily exogenous doses in laying hens were able to increase the number of white follicles, small yellow follicles, and preovulatory follicles, demonstrating the critical role of FSH in all stages of follicular development (Palmer and Bahr, 1992). Thereby, both gonadotropins influence the steroidogenic capacity of the ovary, enabling the production and secretion of estradiol $\left(\mathrm{E}_{2}\right)$ and progesterone $\left(\mathrm{P}_{4}\right.$; Shahabi et al., 1975; Shodono et al., 1975). At the time of sexual maturation, the ovary contains thousands of viable small white follicles (SWF) embedded in the highly vascularized stroma of the ovary (Johnson and Woods, $2009 \mathrm{~b})$, and these follicles are responsible for the production of circulating $\mathrm{E}_{2}$ (Robinson and Etches, 1986). The rise in $\mathrm{E}_{2}$ following photostimulation results in amplified protein synthesis to initiate maturation of the oviduct (Muller et al., 1970), with this demand further increasing prior to the onset of lay when elevated concentrations of $\mathrm{E}_{2}$ and $\mathrm{P}_{4}$ are present (Shahabi et al., 1975; Shodono et al., 1975). Due to the oviparous nature of this species, during maturation $\mathrm{E}_{2}$ targets the liver for the synthesis of yolk proteins deposited into follicles, the skeletal frame and digestive system to coordinate calcium mobilization for shell formation, and the oviduct for the coordination between egg formation and ovulation (Dacke et al., 1993; Walzem et al., 1999).

\section{Photoreception and Photoreceptors Retinal Photoreceptors}

The retina of the eye, through the capture and absorption of photons, is the primary source of photic information by receiving and transmitting images from the external environment to the brain while also contributing in part to the entrainment of the circadian rhythm (Underwood et al., 1984). The retina has 3 types of photoreceptor cells classified as rods, cones and double cones (Perry, 1995). Rod cells are primarily utilized during periods of low illumination, as they are highly sensitive to light, yet they do not detect colour due to the single spectral class (Bowmaker and Knowles, 1977; Yau, 1994; Hart, 2001). Conversely, cone cells can be used at much higher levels of brightness and to determine variations in colour, with avian species being tetrachromatic, meaning they are able to visualize peaks within violet $(415 \mathrm{~nm})$, blue $(455 \mathrm{~nm})$, green (508 nm), and red (571 nm) wavelengths (Yoshizawa, 1992; Perry, 1995; Prescott and Wathes, 1999; Hart, 2001). Initially, retinal photoreceptors were believed to be the only types of photoreceptors, as an early study on migrating junco showed that providing supplemental light to artificially create long days (LDs) resulted in hens laying eggs in the middle of the winter season (Rowan, 1931). However, it was later determined that blind laying hens have a similar rate of egg production when compared to their sighted counterparts, regardless of the presence of retinal photoreceptors (Siopes and Wilson, 1980). This study was one of the first to suggest that the eye is a nonessential component of a hens' neuroendocrine reflex to light, 
indicating it may not be necessary for the photostimulatory response. Since then, further studies have suggested that in fact, input from the retinal photoreceptors may delay sexual maturation, as blind hens and roosters were shown to mature more rapidly than their sighted counterparts (Siopes and Wilson, 1980; Perttula and Bédécarrats, 2012; Baxter et al., 2014).

\section{Extra-Retinal Photoreceptors}

With retinal photoreceptors playing no significant role in mediating the response to photostimulation, transduction of light photons into biological signals is believed to be performed by extra-retinal reception. One of the first studies to show the significance of extra-retinal photoreceptors was conducted by Benoit in 1935 (Benoit, 1935a,b), showing that although sighted and blind ducks displayed similar gonadal growth rates and patterns, when a black cap was placed over the head to prevent deep brain penetration of light, the gonadal response was inhibited. This implied that the avian skull is permeable to light and that light could scatter through and be absorbed by overlapping tissues in order to stimulate encephalic receptors (Foster and Follett, 1985). Thus, emphasis will be put on deep brain photoreception, as the role of the pineal gland and its associated MEL production were discussed in the previous section.

Any photoreceptive molecule outside of the retina is referred to as an extra-retinal photoreceptor. In the avian brain, 4 regions have been proposed to house DBPs; the lateral septal region (LSO), the paraventricular nucleus (PVN), the premammillary nucleus (PMM), and the paraventricular organ (PVO; Kuenzel et al., 2015). Four criteria have also been utilized to determine if new candidate photopigments can be classified as a DBP, including (1) Explicit expression in the photosensitive region of the brain; (2) Physiological capability of the molecule to signal light as an opsin/vitamin A-based photopigment; (3) Appropriate maximum spectral absorption, predicted to be $\sim 492 \mathrm{~nm}$, and (4) Corresponding to the maximum photon capture and spectrum of available light within the hypothalamus (Foster and Helfrich-Förster, 2001; Davies et al., 2012). From there, working models suggest that the components of the avian photoperiodic response are confined to the medio-basal hypothalamus (MBH; Benoit, 1935a,b; Menaker, 1968). To date, it has been proposed that the DBPs involved in priming the reproductive axis include the vertebrate ancient (VA) opsin (a member of the opsin 1 family; OPN1; Foster et al., 1985, 1994; Halford et al., 2009; Davies et al., 2012), melanopsin (OPN4; Chaurasia et al., 2005; Kang et al., 2010), and neuropsin (OPN5; Nakane and Yoshimura, 2010; Ohuchi et al., 2012).

\section{Candidate DBPs for Photo-Induced Sexual Maturation}

Since the first discovery of DBPs, new opsin families have been identified in the hypothalamus. The recent annotation of opsin sequences within the chicken genome has allowed for the identification of five opsin family categories under which all opsins can be classified, including OPN1, OPN3, OPN4, OPN5, and retinal G-protein coupled receptors (RGR;
TABLE 1 | Summary of the candidates for deep brain photoreception.

\begin{tabular}{|c|c|c|c|c|c|c|c|}
\hline \multirow[t]{2}{*}{ Family } & \multirow[t]{2}{*}{$\begin{array}{l}\text { Opsins } \\
\text { consolidated }\end{array}$} & \multirow[t]{2}{*}{$\begin{array}{l}\text { Wavelengths } \\
\text { (nm) }\end{array}$} & \multirow[t]{2}{*}{ Expression } & \multicolumn{4}{|c|}{$\begin{array}{l}\text { DBP } \\
\text { criteria }\end{array}$} \\
\hline & & & & 1 & 2 & 3 & 4 \\
\hline \multirow[t]{3}{*}{ OPN1 } & $\begin{array}{l}\text { Vertebrate ancient } \\
\text { (VA) Opsins }\end{array}$ & $450-520$ & $\begin{array}{l}\text { Pineal gland } \\
\text { Hypothalamus }\end{array}$ & $\checkmark$ & $\checkmark$ & $\checkmark$ & $\checkmark$ \\
\hline & Rhodopsin & $480-495$ & $\begin{array}{l}\text { Pineal gland } \\
\text { Skin } \\
\text { Retina }\end{array}$ & $x$ & $\checkmark$ & $\checkmark$ & $\checkmark$ \\
\hline & Pinopsins & $480-540$ & Pineal gland & $x$ & $\checkmark$ & $\checkmark$ & $\checkmark$ \\
\hline \multirow[t]{2}{*}{ OPN3 } & $\begin{array}{l}\text { Teleost multiple } \\
\text { tissue (TMT) opsins }\end{array}$ & $450-470$ & $\begin{array}{l}\text { Cerebellum } \\
\text { Retina } \\
\text { Paraventricular } \\
\text { nucleus }\end{array}$ & $x$ & $\checkmark$ & $x$ & $x$ \\
\hline & Encephalopsins & & $\begin{array}{l}\text { Cerebellum } \\
\text { Thalamic nuclei }\end{array}$ & $x$ & $\checkmark$ & $x$ & $\mathrm{x}$ \\
\hline OPN4 & Melanopsins & $410-480$ & $\begin{array}{l}\text { Hypothalamus } \\
\text { Pineal gland } \\
\text { Retina }\end{array}$ & $\checkmark$ & $\checkmark$ & $x$ & $x$ \\
\hline OPN5 & Neuropsin & $350-470$ & Hypothalamus & $\checkmark$ & $\checkmark$ & $x$ & $x$ \\
\hline \multirow[t]{2}{*}{ RGR } & $\begin{array}{l}\text { Retinal G } \\
\text { protein-coupled } \\
\text { receptors }\end{array}$ & $470-490$ & Retina & $x$ & $\checkmark$ & $x$ & $x$ \\
\hline & Peropsins & & Pineal gland & $x$ & $\checkmark$ & $x$ & $x$ \\
\hline
\end{tabular}

The five families of opsins broken down into their components, along with their associated wavelength of spectral absorption $(\mathrm{nm})$, the signaling pathway they utilized and where they are expressed in the chicken. Wavelengths indicated in $B O L D$ are within the $492 \mathrm{~nm}$ maximum spectral absorption hypothesized to be associated with reproduction. The deep brain photoreceptor (DBP) criteria refer to (1) Explicit expression in photosensitive regions of the brain; (2) Physiological capability of the molecule to signal light as an opsin/vitamin A-based photopigment; (3) Appropriate maximum spectral absorption, predicted to be $\sim 492 \mathrm{~nm}$; and (4) Correspond to the maximum photon capture and spectrum of available light within the hypothalamus (Foster and Follett, 1985; Davies et al., 2012).

Table 1). The family of OPN1 includes VA-opsin, expressed in the hypothalamus and pineal gland, as well as rhodopsin, expressed in the retina and pineal gland (Foster et al., 1985, 1994; Halford et al., 2009; Davies et al., 2012). Conversely, members from the OPN3 family consist of teleost multiple tissue opsins (TMTs) found in the cerebellum, retina and the PVN of the hypothalamus, and encephalopsins found in the cerebellum as well as the thalamic nuclei (Kato et al., 2016), suggesting this family does not play a role in reproductive control due to its localization outside the light-sensitive regions associated with reproduction. Similarly, with RGR expressed in the retina and pineal gland rather than the brain, evidence supports a role in circadian rhythm and vision rather than reproduction (Díaz et al., 2017). Meanwhile, two additional candidates, OPN4 and OPN5 were identified within various photosensitive regions throughout the hypothalamus (Chaurasia et al., 2005; Kang et al., 2010; Nakane and Yoshimura, 2010; Ohuchi et al., 2012), with OPN4 also expressed in the pineal gland (Chaurasia et al., 2005; Kang et al., 2010), and the retina (Tomonari et al., 2005). Thus, based on location, OPN1, OPN4, and OPN5 appear to be the best candidates to act as mediators of photoperiod on reproduction and are further discussed below. 


\section{Melanopsin (OPN4)}

Melanopsin is a photopigment often referred to as OPN4, due to its gene of origin (Hankins et al., 2008b). Originally isolated in the melanophores of Xenopus (Provencio et al., 1998), this protein was later found in the diencephalon, pineal gland, and retina of the chicken (Foster et al., 1987; Bailey and Cassone, 2005; Chaurasia et al., 2005; Tomonari et al., 2005; Kang et al., 2010) and, due to its role in non-image light detection, it was proposed as a candidate DBP impacting the HPG axis (Freedman et al., 1999; Peirson and Foster, 2006; Hankins et al., 2008b). At the time, two isoforms were identified in avian species including OPN4M (mammalian-like) and OPN4X (xenopuslike; Bellingham et al., 2006; Hankins et al., 2008a). In the turkey, OPN4X mRNA has been found in dopamine (DA)expressing neurons of the brain, including in the PMM, as well as in MEL expressing neurons (Kang et al., 2010; Kosonsiriluk et al., 2012). The Dopamine-Melatonin (DA-MEL) neurons are activated upon interruption of the dark phase with various light periods from $30 \mathrm{~min}$ to $3 \mathrm{~h}$ when the birds are within the photoresponsive phase of reproduction, leading to decreased expression of OPN4X and MELergic activity, while DAergic activity is elevated (Kang et al., 2010). Increased DAergic activity has been implicated in GnRH-I and Vasoactive Intestinal Peptide (VIP) signaling (Bhatt et al., 2003; Chaiseha et al., 2003; Kang et al., 2006), possibly through the alteration of thyroid stimulating hormone (TSH), and type 2 deiodinase (DIO2) activity (Kang et al., 2010). While this evidence supports the role of melanopsin in the control of reproduction in the turkey hen, this connection has yet to be established in the domestic chicken. Although OPN4 is present in the brain of day-old chicks (Chaurasia et al., 2005), no expression has been found in the hypothalamus of maturing birds (Chaurasia et al., 2005; Hankins et al., 2008a). Furthermore, with an absorption spectrum between $410-480 \mathrm{~nm}$, OPN4 fails to reach the predicted maximum spectral absorption of $492 \mathrm{~nm}$ for deep brain perception (Foster and Follett, 1985). Altogether, this indicates that while melanopsin may play a role in the photoperiodic response, it is unlikely to be the key opsin triggering the initiation of sexual maturation.

\section{Neuropsin (OPN5)}

Neuropsin is encoded by the OPN5 gene (Tarttelin et al., 2003), localized in the cerebrospinal fluid (CSF)-contacting neurons of the PVO within the MBH (Halford et al., 2009; Nakane and Yoshimura, 2010), meeting the location criteria outlined for a potential DBP. However, OPN5 is also expressed in the adrenal glands with a possible role in chemosensory reception (Ohuchi et al., 2012). Nonetheless, it has been the subject of a number of studies for its potential role in controlling reproduction. It was determined that OPN5 has two isoforms including an ultra-violet (UV) light-absorbing form that possesses a 11-cis-retinal with a maximum absorption at $360 \mathrm{~nm}$, and a visible light-absorbing form altered by the addition of all-trans-retinal maximally absorbed at $474 \mathrm{~nm}$ (Yamashita et al., 2010). This indicates that this photopigment is bi-stable, signifying its ability to absorb two light spectra, and may interact with reproductive control in some capacity under either UV or visible light (Yamashita et al., 2010). While these molecules are both capable of signaling light within the hypothalamus, these absorption maxima fall short of the predicted wavelength requirements and, simply transitioning birds from short to LDs did not alter the expression of OPN5 (Yamashita et al., 2010; Stevenson and Ball, 2012). It has been proposed that light detected by OPN5-positive CSF-contacting neurons allows information to be transmitted to the pars tuberalis (PT) to induce TSH- $\beta$ mRNA expression (Nakao et al., 2008), thereby suggesting that OPN5 plays a role in the activation of the HPG axis (Nakane et al., 2014). Interestingly, evidence that OPN5 is coupled to the $\mathrm{G}_{\mathrm{i}}$ (inhibitory) subunit (Yamashita et al., 2010), along with OPN5 knockdown or gene silencing via smallinterfering RNA (siRNA) disrupting the photoperiodic control of reproduction, has supported the theory that OPN5 could play an inhibitory role. One particular study used antisense sequences found to reduce the expression of OPN5 by 32\% compared to the scrambled sequence and, birds demonstrated an elevation in TSH- $\beta$ levels with the decline in OPN5 when photostimulated by LD under white light (Stevenson and Ball, 2012). A more recent study has demonstrated that knockdown of OPN5, in conjunction with pinealectomy and eye patches, suppressed the production of TSH- $\beta$ traditionally stimulated by LD when housed under UV-lighting (Nakane et al., 2014). By utilizing UV-light, Nakane et al. (2014) were able to directly stimulate the OPN5 photoreceptors, explaining the opposing results of Stevenson and Ball (Stevenson and Ball, 2012), in which the photoreceptors non-responsive to UV stimulation had not been isolated. With an inhibitory impact in mind, future studies should explore a possible interaction between OPN5 and GnIH. Interestingly, it appears that expression of OPN5 is age-dependent, with expression increasing throughout maturity in male quail up to 16 weeks of age (woa), yet by 144 woa expression had decreased (Banerjee et al., 2018). Further studies in females would provide insight into these age-related changes in OPN5 and whether they correlate with sexual maturation and the dissipation of juvenile photorefractoriness.

\section{Vertebrate Ancient (VA)-Opsin}

Vertebrate Ancient-opsin, first identified in the Atlantic salmon (Soni and Foster, 1997; Soni et al., 1998), is a functional photopigment belonging to the OPN1 family. In the chicken, two isoforms, cVALong (cVAL), and cVAShort (cVAS), have been identified (Halford et al., 2009). With a spectral peak of $491 \mathrm{~nm}$, perikarya localized in the $\mathrm{MBH}$, and projections extending into the ME, VA-opsin satisfies all the proposed criteria for a DBP mediating photoperiodic response (Young, 1962; Hankins et al., 2008b; García-Fernández et al., 2015). Indeed, current working hypotheses suggest VA-opsin perikarya in the $\mathrm{MBH}$ are responsible for photoreception, with the projections sent to the posterior portion of the hypothalamus, through to the ME, allowing for interactions with the PT (García-Fernández et al., 2015). This would suggest that VA-opsin neurons may interact with pituitary thyrotropes to produce TSH, eliciting the response of thyroid hormones to activate the HPG axis, as described below. However, while these perikarya may be the primary site of photoreception, it is also possible that the fibers of VA-opsin neurons form a photosensitive net, responding to light directly within the ME rather than indirectly stimulating this region. 
Recently, it was shown that VA-opsin is co-expressed with $\mathrm{GnRH}$ in perikarya present in the anterior and medial hypothalamus with projections to the ME (García-Fernández et al., 2015), corresponding to regions previously identified with GnRH (Foster et al., 1987; Dawson et al., 2001). While this suggests a direct link between VA-opsin photoreception and GnRH-I synthesis and release, the timing of GnRH-I release corresponds to the activation of the HPG axis (Ni et al., 2013), rather than anytime during the photosensitive period that precedes the trigger of photostimulation itself. Therefore, these discrepancies in timing signify that while this photoreceptor may interact with GnRH-I to activate sexual maturation, it is unlikely that VA-opsin is able to directly stimulate the HPG axis and its mode of action remains unknown. Similar to neuropsin, VA-Opsin mRNA, along with the number of ir-VA-Opsin cells, have been suggested to be elevated from the immature state through to the period of sexual maturation, from 6 to 16 woa in the male quail, with a decline observed at 144 woa (Banerjee et al., 2018). Furthermore, as VA-Opsin and GnRH-II perikarya have been identified to be expressed within similar regions, with projections extending to various additional regions of the brain outside of the ME (Sharp et al., 1990; García-Fernández et al., 2015), a possible relationship may exist and should be investigated. Interestingly, VA-Opsin also strongly co-localizes with argininevasotocin (AVT; García-Fernández et al., 2015), a system known to cause oviposition by triggering contractions of the shell gland in avian species (Koike et al., 1988), via an upregulation of local prostaglandin production (Rzasa, 1978, 1984). Since AVT has also been linked to the stimulation of prolactin (PRL), adrenocorticotropic hormone (ACTH), and pro-opiomelanocortin (POMC; El Halawani et al., 1992; Wu et al., 2019), this raises the possibility that VA-opsin, in addition to contributing to the photo-induced activation of the HPG axis, may also contribute to the initiation of lay, as well as the control of oviposition timing via PRL (Harvey et al., 1979a). The implications of POMC along with its cleavage product ACTH on the neuroendocrine response of reproduction are discussed at length later in this review.

\section{Downstream Effects of Deep Brain Photoreception}

While the exact characterization of hypothalamic photoreceptors remains elusive, the detection of light via photoreception and the cascade of succeeding events have been well established. It is known that longer daylength, integrated via a molecular clock contained within the MBH (Yasuo et al., 2003), will lead to the stimulation of thyrotrope cells in the PT of the pituitary to release TSH. TSH then acts on the specialized ependymal cells, referred to as tanycytes, contained within the third ventricle and believed to be critical for the induction of the HPG axis. Subsequent stimulation of these tanycytes will elicit an upregulation in the expression of DIO2 enzyme (Nakao et al., 2008). DIO2 is a thyroid hormone-activating enzyme responsible for the conversion of the prohormone, thyroxine $\left(\mathrm{T}_{4}\right)$, into the bioactive form, triiodothyronine $\left(\mathrm{T}_{3}\right.$; Bernal, 2002). It has been determined that DIO2 is directly induced through light stimulation during the photosensitive phases, however, this same elevation in expression is not observed when stimulation is provided outside of the photosensitive phase, meaning that DIO2 expression is upregulated under $\mathrm{LD}$ and downregulated under short day (SD; Yoshimura et al., 2003). At the same time, expression of a thyroid hormone-inhibiting enzyme, type 3 deiodinase or DIO3, was reported to act in an opposing fashion to DIO2 (Yasuo et al., 2005). The reciprocal relationship between these enzymes allows for a refined activity control of thyroid hormones within the $\mathrm{MBH}$, occurring $18 \mathrm{~h}$ after dawn on the first day of photostimulation (Nakao et al., 2008). There is strong evidence suggesting TSH- $\beta$ is a trigger for the expression of DIO2/DIO3. TSH- $\beta$ is expressed in the PT $14 \mathrm{~h}$ after dawn, approximately $4 \mathrm{~h}$ prior to the release of DIO2/DIO3 (Nakao et al., 2008). This indicates that TSH under the influence of LD could be a key factor in the regulation of reproduction in birds (Yoshimura, 2013). Elevated levels of $\mathrm{T}_{3}$ in the $\mathrm{MBH}$ target thyroid hormone receptors in the ME (Yoshimura et al., 2003). GnRH nerve terminals, residing in the ME, will allow for the release of $\mathrm{GnRH}$ in response to these elevations, thereby activating the HPG axis (Hanon et al., 2008; Hazlerigg and Loudon, 2008; Nakao et al., 2008). This occurs as a result of morphological changes between GnRH nerve terminals and glial endfeet (Yamamura et al., 2004). Under SD, prior to the photostimulatory period, these GnRH nerve terminals are unable to contact the basal lamina as they are encased by the endfeet of glial processes. However, with the shift to $\mathrm{LD}$, these nerve terminals are able to interact with the basal lamina, deemed critical as the neuropeptides must be secreted into the portal capillary system (Prevot et al., 1999; Yamamura et al., 2006). Additional studies have shown that local administration of $\mathrm{T}_{3}$ to the $\mathrm{MBH}$ has the ability to imitate these morphological changes to the GnRH nerve terminals, even under SD, outlining the importance of thyroid hormones to the reproductive process (Yamamura et al., 2006).

\section{HYPOTHALAMIC INTEGRATION OF APPETITE CONTROL AND REPRODUCTION}

\section{Appetite Control and the Melanocortin System}

First and foremost, it is important to understand the integration of hypothalamic signals contributing to feed intake as it will ultimately impact body weight and composition of the hen. It is well established that the melanocortin system is responsible for monitoring energy status and controlling appetite. This occurs through the combined effects of POMC and cocaine and amphetamine-regulated transcript (CART) to downregulate hunger, as well as agouti-related peptide (AgRP), and neuropeptide Y (NPY) to upregulate feed intake. In addition, 5 melanocortin receptors have been identified, all of which are expressed in the avian brain (Takeuchi et al., 1996, 1998, 1996, 2000; Berghman et al., 1998; Takeuchi and Takahashi, 1998, 1999). 
Initial studies showed that during periods of food deprivation or negative energy balance (Phillips-Singh et al., 2003; Higgins et al., 2010; Song et al., 2012), hens display elevated co-expression of orexigenic hormones, AgRP and NPY. Both peptides have been identified in the MBH of the ring dove (Strader and Buntin, 2003; Strader et al., 2003), as well as the infundibular nucleus (IN) in quail, which is the equivalent to the mammalian arcuate nucleus (ARC; Boswell et al., 2002), while NPY has been identified in the IN of the chicken (Kameda et al., 2001). Levels of AgRP have been reported to increase with the duration of food deprivation (Phillips-Singh et al., 2003; Higgins et al., 2010; Song et al., 2012), yet, strong evidence suggests these levels can be restored between 24 and $48 \mathrm{~h}$ following re-introduction to feed, depending upon the duration of deprivation (Harrold et al., 1999; Mizuno and Mobbs, 1999; Wilson and Bagnol, 1999; Higgins et al., 2010; Lei and Lixian, 2012; Song et al., 2012; Dunn et al., 2013; Fang et al., 2014). Levels of NPY mRNA were additionally found to elevate during periods of restricted feeding (Song et al., 2012) and, central injection of this peptide can stimulate feed intake in chickens (Kuenzel et al., 1987) and white crowned sparrows (Richardson et al., 1995). Thus through the coordination of NPY and AgRP (Hahn et al., 1998; Chen et al., 1999), the orexigenic portion of the melanocortin system is able to respond to declining energy status and hunger signals.

Conversely, gene expression of the anorexigenic hormones, POMC and CART, significantly decrease due to reduced food availability (Higgins et al., 2010). The co-expression of CART and POMC has not yet been published in chickens, yet CART neuronal cell bodies have been found in the IN of zebra finches (Singh et al., 2016). Although CART is able to decrease feed intake in ad libitum fed broilers and layers, it had no impact on feed restricted layers, while intracerebroventricular (ICV) injection did induce a dose-dependent decline in the feed intake of restricted broilers (Tachibana et al., 2003). Additionally, CART is able to partially inhibit NPY-induced feeding (Tachibana et al., 2003), but the mechanism of action is unknown. POMC is expressed in the IN of the hypothalamus, along with NPY and AgRP in quail (Boswell et al., 2002), as well as in chickens (Gerets et al., 2000). However, results have shown inconsistencies, as some studies have demonstrated that levels of POMC mRNA decrease after 7 days of restricted feeding in both layers and broilers (Hen et al., 2006), with others showing no changes in this anorexigenic peptide, demonstrating that AgRP mRNA is a much more reliable measurement (Dunn et al., 2013). Interestingly, while no differences in POMC mRNA were observed after $24 \mathrm{~h}$ of fasting, a significant decline occurred at $36 \mathrm{~h}$ (Ren et al., 2017), indicating that this hormone may not be the primary cause of the anorexigenic effects observed, but rather a result of the activated pathway. As a precursor polypeptide, POMC is cleaved into various key hormones, including ACTH, alpha-, beta-, and gammamelanocyte stimulating hormone ( $\alpha-\mathrm{MSH}, \beta-\mathrm{MSH}$, and $\gamma-\mathrm{MSH})$, and $\beta$-endorphin (Takeuchi et al., 1999). While $\alpha$-MSH is involved in decreasing feed intake through the central nervous system by interacting with melanocortin receptor subtype 4 (MC4R; Mountjoy et al., 1994), ACTH is a key link between regulation of appetite and stress response via the hypothalamicpituitary adrenal (HPA) axis (Aguilera, 1994), further decreasing feed intake when injected (Kawakami et al., 2000; Strader et al., 2003; Cline et al., 2008; Shipp et al., 2016). However, it has also been demonstrated that $\alpha$-MSH can trigger the release of corticosterone (CORT) in a dose-dependent manner, supporting further integration of the HPA axis in appetite control (Tachibana et al., 2007). Yet, ostrich- $\beta$-endorphin has been reported to stimulate feed intake of pigeons immediately after ICV injection (Deviche and Schepers, 1984). The opposing role of this POMC cleavage product may offer insight into the aforementioned inconsistencies of the mRNA levels of the peptide during states of feed deprivation.

These melanocortins can elicit their response through any of the 5 receptor subtypes, however, unlike mammals, avian receptors possess a higher affinity for ACTH in comparison to that of $\alpha-\mathrm{MSH}$ (Ling et al., 2004), pointing to a larger role for the stress response in appetite control. This alteration in avian species has been predicted to result from the absence of the intermediate lobe of the pituitary in the chicken, allowing ACTH to become the predominant melanocortin signal (Boswell and Takeuchi, 2005). Melanocortin receptors are able to stimulate various responses ranging from the regulation of energy expenditure, through receptor subtype 3 (MC3R), to food intake control, through MC4R. Due to the localization of MC3R and MC4R in the hypothalamus of the chicken, these subtypes have been heavily studied for their contributions to energy homeostasis (Ka et al., 2009; Higgins et al., 2010; Song et al., 2012; Yi et al., 2015). While $\alpha-\mathrm{MSH}$ acts as an agonist of MC4R to inhibit feed intake in periods of satiety, AgRP has been found to antagonize the activity of ACTH and $\alpha-$ MSH on MC3R and MC4R (Zhang et al., 2017), demonstrating the ability of the melanocortin system to achieve energy homeostasis through competitive interactions with the receptors. However, each of these receptor subtypes are expressed in various tissues, ranging from the brain to the liver, playing a role in the integration of metabolic processes and appetite. Expressed in melanocytes, MC1R is primarily involved with $\alpha$-MSH regulation of feather pigment (Teshigawara et al., 2001). Meanwhile, MC2R and MC $3 R$ are expressed in the adrenals, mediating the effects of ACTH on the HPA axis (Takeuchi et al., 1998; Takeuchi and Takahashi, 1999), and MC5R was the only receptor subtype present in the liver of the chicken (Ren et al., 2017). Additionally, NPY is known to act via its receptor subtypes, NPYR1 through NPYR5, which have been implicated in adipogenesis and early broiler growth (Resnyk et al., 2013; Shipp et al., 2016). Currently, NPYR1 has been hypothesized to be associated with most orexigenic activity elicited by NPY, according to studies conducted in mice (Gehlert, 1999). NPY1R and NPY5R mRNA have an elevated expression in the hypothalamus of low weight selected hens, compared to that of their high weight selected counterparts. However, these receptors were alternatively higher in adipose tissue of the high weight selected hens, compared to the low (Zhang et al., 2013). This differential receptor expression could implicate NPY in alternative pathways, diverting energy from fat storage to utilization, requiring further investigation in the sexual maturation of the laying hen. 


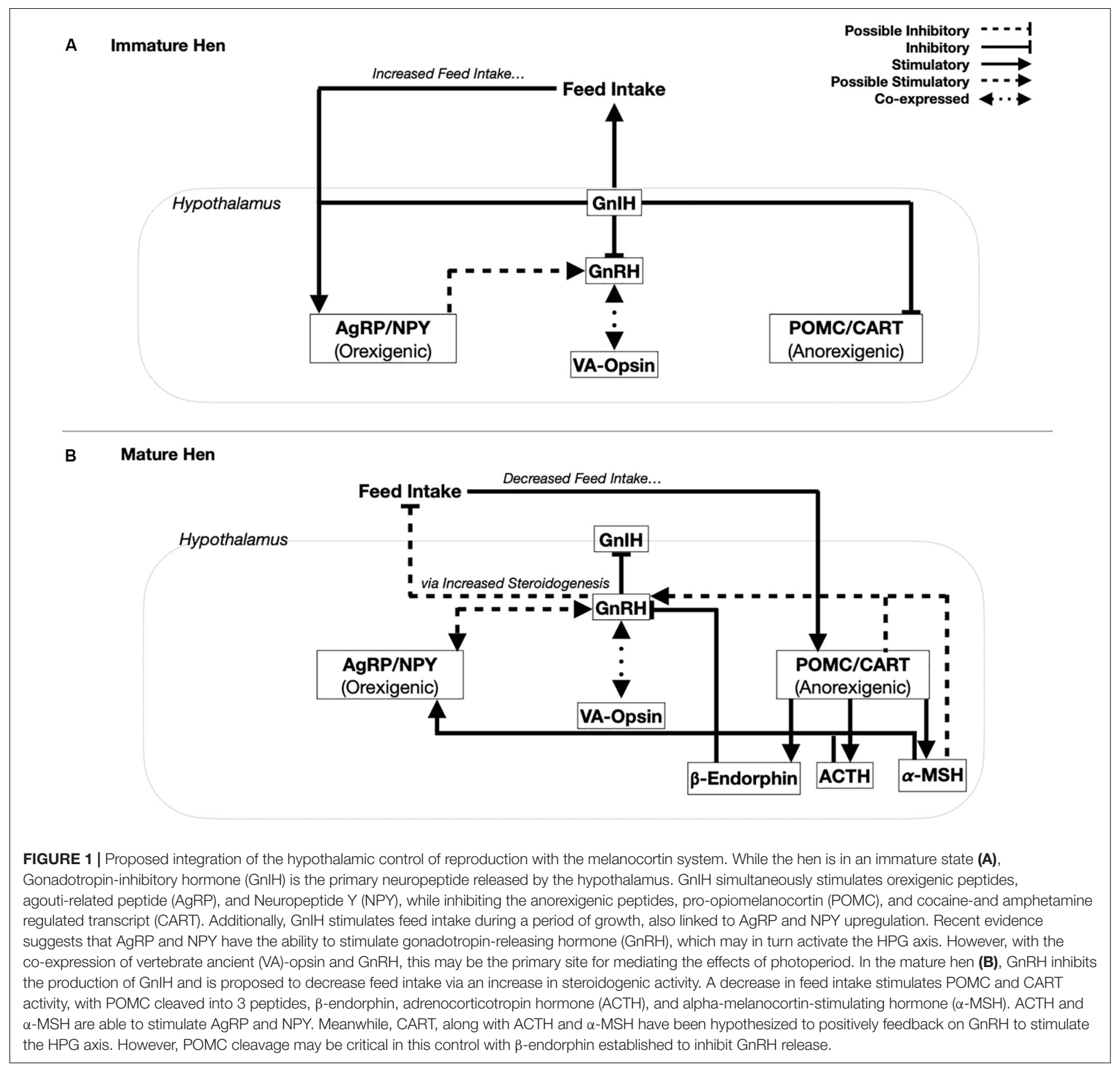

Recently, melanocortin receptor accessory proteins (MRAPs) have been reported to support and alter the interactions of the receptors within the melanocortin system. In the chicken, MRAP is expressed in the brain, in addition to the adrenal gland, liver, spleen, stomach and lungs (Ren et al., 2017), while MRAP2 is expressed predominately in the brain (Asai et al., 2013). Currently, much of the work surrounding these accessory proteins has been completed in mammals, where MRAP2 has been linked to growth and metabolism (Cone, 2006; Asai et al., 2013; Sebag et al., 2013), interacting directly with MC4R in the brain to enhance cAMP production driven by the receptor in mice (Asai et al., 2013). Consequently, MC4R, linked to anorexigenic activity via ACTH, has also been found to act as an $\mathrm{ACTH}$ receptor in the presence of MRAP2 in zebrafish (Agulleiro et al., 2013). Additionally, in chickens it appears that while MRAP and MRAP2 have the ability to decrease MC4R and MC5R expression in the plasma membrane, they have no effect on the remaining MCRs (Ren et al., 2017).

While the melanocortin system was initially believed to be the primary source of control involved in appetite regulation, involvement of these peptides in reproductive regulation has been proposed and will be discussed at length, as summarized in Figure 1. In addition, reproductive neuropeptides have been reported to play a role in the control of appetite and this integration will be considered. 


\section{Integration Between the Melanocortin System and Reproduction}

\section{Effects of the Orexigenic System on Reproduction}

NPY is one of the most potent orexigenic regulators of food intake (Hill et al., 2008; Pralong, 2010; Boswell, 2011), while also believed to control reproduction through its influence on ovulation (Dunn et al., 2004; Wu et al., 2007; Li et al., 2009). Predominantly, NPY is hypothesized to elicit its response through the stimulation of GnRH secretion (Contijoch et al., 1993), as NPY perikarya are located in the hypothalamus, with mRNA, peptide, and fibers located in the ME and fibers in the PVN, aligning with the location of GnRH-I and GnIH perikarya and fibres (Kuenzel, 2000; Singh et al., 2013). In addition, central injections of NPY can induce a premature LH surge in chickens (Contijoch et al., 1993) and mammals (Kalra et al., 1997), implicating NPY in the promotion of earlier sexual maturation (Fraley and Kuenzel, 1993). Furthermore, mutations in NPY favouring heterozygote DraI +/ - are associated with an earlier age at first egg (AFE; Dunn et al., 2004), compared to homozygous DraI +/+ or DraI -/ - and may be correlated with the total number of eggs laid (Wu et al., 2007). Interestingly, it was determined that these same mutations in NPY DraI influence body weight at the time of sexual maturation, with a higher breeding value determined for the heterozygote (Fatemi et al., 2012), further suggesting a possible link between metabolism and reproduction.

As AgRP is co-expressed with NPY, this peptide likely also influences reproduction in chickens, yet few studies have considered this relationship. It is known that AgRP mRNA levels increase during incubation in hens, however, in this same study, voluntary decrease in feed intake observed in incubating hens was not found to differ from pair-fed hens, while those released from feed restriction demonstrated a significant decline in this peptide (Dunn et al., 2015). Additionally, AgRP mRNA levels in roosters were found to be higher during the photosensitive periods, while declining in periods of photorefractoriness, corresponding to a period with lower body weight and feed intake (Banerjee and Chaturvedi, 2018). AgRP has also been found to play a role in the reproductive system of other species, with mRNA levels declining following ICV of $E_{2}$ in mice (Olofsson et al., 2009), and mRNA levels significantly increasing at the beginning of a breeding season in ewes while lower levels are present at the end of this period (Clarke et al., 2000). Thus, from information gathered from other species, it is likely that in laying hens AgRP expression increases prior to the initial peak of $\mathrm{E}_{2}$, at a time when energy is needed for both growth and sexual maturation processes. Levels would then be expected to decrease thereafter, as the hen switches metabolic demand from growth to reproduction. Nonetheless, this hypothesis still needs to be tested.

\section{Effects of the Anorexigenic System on Reproduction}

There is currently a gap in the literature surrounding the role of POMC during the process of sexual maturation in the laying hen. One study, involving the Shaoxing duck, reported a peak in POMC mRNA levels approximately 30 days prior to the elevation of GnRH-I mRNA (Ni et al., 2011). This is the first reported alteration in POMC expression during this time in an avian species. Throughout a laying cycle, POMC mRNA levels have been reported to remain unchanged among laying and non-laying broiler breeder hens with paired body weight (Dunn et al., 2013), as well as in bantam hens in the laying and incubation phases (Dunn et al., 2015). While this would suggest that this peptide is not implicated in the reproductive status of the hen, the activity of the cleavage products of POMC reveal a contrasting interpretation. Treatment of broiler chicks with $\alpha$-MSH via ICV showed elevated expression of NPY and AgRP in the IN, indicating a potential homeostatic feedback mechanism to balance the dual control of the melanocortin system (Delp et al., 2017), and an indirect stimulatory role in the control of the HPG axis. Conversely, endogenous opioid peptides have been found to play an opposing role as $\beta$-endorphin has been linked to the suppression of LH release and ovulation after administration into the third ventricle of white leghorn laying hens (Sakurai et al., 1986), while [Met]-enkephalin was found to exert an inhibitory response on the release of GnRH in the cockerel by reducing the response to depolarization in vitro (Stansfield and Cunningham, 1987) due to the close proximity of these neurons to that of GnRH (De Lanerolle et al., 1981; Sterling and Sharp, 1982). Taken together, these results imply that while the expression of POMC remains constant throughout a laying cycle, evaluation of the cleavage products would be more appropriate to assess the underlying activity of this peptide and its effects on the hypothalamic release of GnRH and or GnIH.

Similar to that of POMC, the role of CART during sexual maturation remains relatively unknown. CART mRNA was initially reported to be primarily present in the hypothalamus and pituitary gland of adult laying hens and its peptide undetectable in the ovary (Cai et al., 2015). Since, it has been established that CART mRNA is present within subsets of follicles with the highest expression in the theca layer of large white follicles compared to the pre-ovulatory follicles (Li et al., 2017), ultimately suggesting that CART does in fact have a role, which has yet to be determined in avian species. When considering mammalian literature, CART has been identified to be under the control of LEP (Douglass, 1995; Gautvik et al., 1996; Kristensen et al., 1998; Rogge et al., 2008), be responsible for regulating the stress response (Koylu et al., 2006), the energy balance (Kristensen et al., 1998; Rogge et al., 2008), and bone remodelling (Elefteriou et al., 2005) in rodents, as well as ovarian follicle development in bovine (Kobayashi et al., 2004; Sen et al., 2007). Specifically in rats, elevated hypothalamic CART mRNA levels were found to decrease GnRH-I interpulse intervals, increasing the frequency (Lebrethon et al., 2000). Additionally, CART mRNA was found to inhibit FSH signaling in cattle (Sen et al., 2007, 2008). Thus, although limited information is available on the role of CART in avian species, as for POMC, literature in mammals suggests an overall suppressive role.

\section{Melanocortin Receptors and Reproduction}

As previously mentioned, MC5R is the only receptor subtype reported to be expressed in the liver, which is of particular interest as the liver is known to form yolk lipoproteins throughout the laying cycle (Walzem et al., 1999). Since this process is under the 
influence of $\mathrm{E}_{2}$, a potential interaction between the melanocortin and reproductive systems may occur in this organ to control and direct liver metabolism based on the status of the animal. Based on a previous study, MC5R expression appears to be unaffected by $\mathrm{E}_{2}$ treatment (Ren et al., 2017). However, although the role of MC5R remains uncertain, recent studies in chicken demonstrated that MRAP is significantly upregulated by $E_{2}$ in the liver (Ren et al., 2017), possibly via peroxisome proliferatoractivated receptor gamma (PPAR- $\gamma$; Mangelsdorf et al., 1995), as PPAR- $\gamma$ gene expression increases with rising $E_{2}$ levels and decreases with age (Ren et al., 2017). Interestingly, changes in MRAP were not found to have any influence on MC5R expression in the liver (Ren et al., 2017).

\section{Influence of Reproductive Neuropeptides on Appetite Control}

While activation of the HPG axis is integrated with a number of hormones, photoreceptors, and signaling pathways, it has become increasingly apparent that these same reproductive neuropeptides have the ability to influence feed intake in avian species, thereby altering the melanocortin system. Just as $\mathrm{GnRH}$ and $\mathrm{GnIH}$ act as a dual control system on the HPG axis (Bédécarrats, 2015), they have also been observed to play a similar dual control on appetite. For example, in layer chicks $\mathrm{GnIH}$ is known to stimulate feed intake (Tachibana et al., 2005) in an orexigenic fashion by stimulating NPY and inhibiting POMC in the hypothalamus (McConn et al., 2014). It has been hypothesized that this effect on feed intake stems from the inhibition of the remainder of the HPG axis, as feed intake has been observed to increase with the decline in steroidogenesis of Japanese quail (Satake et al., 2001), and decrease with E2 administration in laying hens (Jaccoby et al., 1995). While in the laying hen there has been no difference identified in GnIH neuron activity between ad libitum fed and feed restricted hens (Ciccone et al., 2007), an increase in GnIH activity is observed after $48 \mathrm{~h}$ of deprivation in the Peking duck (Fraley et al., 2013). Whether this effect is species specific or genetically altered by divergent breeding goals requires further investigation. Meanwhile, since $\mathrm{GnIH}$ is able to suppress the activity of GnRH-I, it could be hypothesized that this stimulatory neuropeptide would play an anorexigenic role in birds. However, as previously discussed, the endogenous opioid peptide $\beta$-endorphin has been reported to have a tonic inhibitory effect on the expression of LH (Sakurai et al., 1986; Stansfield and Cunningham, 1987). Interestingly, processes from CART neurons are in close proximity to $\mathrm{GnRH}$ perikarya in numerous mammalian species (Leslie et al., 2001; True et al., 2013) and such a relationship should be evaluated in avian species. If CART does in fact stimulate GnRH-I, evidence of the co-expression of CART with $\alpha$-MSH, observed in rodents (True et al., 2013), suggests that the activation or suppression of GnRH may depend on the cleavage of the POMC molecule. Further studies will be required to determine whether or not GnRH-I plays an anorexigenic role in the melanocortin system. While this role of GnRH-I is unclear, the activity of the orexigenic response to this neuropeptide has been confirmed with NPY able to stimulate an LH surge in laying hens (Contijoch et al., 1993). However, with the ability of NPY to stimulate corticotrophin releasing factor (CRF) upregulation ( $\mathrm{Li}$ et al., 2000), and the known integration of CRF neurons with GnRH-I cells observed in rats (Maclusky et al., 1988), it is suggested that this LH surge is likely due to the direct stimulatory effect of NPY on GnRH-I. Altogether, this highlights a possible pathway for the integration of metabolic signals and the HPG axis, leading to the hypothesis that immature hens with higher expression of $\mathrm{GnIH}$ would continue to grow due to the stimulation of feed intake. This increase in feed intake will be associated with an elevation in NPY expression, eventually allowing an elevation in GnRH-I to occur to activate the HPG axis.

\section{IMPACT OF BODY WEIGHT AND COMPOSITION ON THE HPG-AXIS}

In many species, it has been shown that obesity is strongly linked to reproductive deficiencies. In humans, obesity in women has been linked to poor conception and implantation rates (Brewer and Balen, 2010), while obesity in mice results in a reduction in oocyte and preantral follicle numbers (Sagae et al., 2012). In layers, diet-induced obesity increased proapoptotic effects in granulosa cells through altered steroidogenesis, causing a decrease in reproductive capacity (Walzem and Chen, 2014). However, while obesity is clearly negatively correlated to reproduction, excessively low body weight is also of concern, leading to the development of the "critical weight hypothesis" which was further confirmed in broiler breeders (van der Klein et al., 2018; Zuidhof, 2018). This hypothesis stipulates that puberty in immature animals could not be predicted by age, but rather by the accumulation of body fat stores (Frisch and McArthur, 1974). Over the years, this hypothesis has been put to the test and while insufficient fat stores have been found to delay the onset of sexual maturation in rats, rapid accumulation of these stores can lead to puberty, even if these animals are still well below target body weight (Ronnekleiv et al., 1978), however, the dynamics and pathways behind this concept have yet to be explored in the hen. While studies have considered the effect of food availability on reproductive success in wild species of seasonal breeders, in the domestic laying hen food availability is not a limiting factor and control of the reproductive axis is achieved mostly by modulating environmental conditions, such as photoperiod. As demonstrated in a recent trial involving Lohmann LSL-Lite, current commercial strains do not necessarily require photostimulatory cues in order to initiate the reproductive process (Baxter and Bédécarrats, 2019). This suggests that sexual maturity is not exclusively triggered by photoperiodic cues, but rather hens are required to reach a critical threshold in body weight or fat composition in order to enter lay (Zuidhof, 2018; Baxter and Bédécarrats, 2019). In terms of the HPG axis, this suggests that additional factors can overcome the inhibitory mechanisms in place prior to photostimulation.

This is in line with previous reports showing that a particular body weight target and degree of body fat is required in order to achieve the initiation of maturation in both broiler breeders and quail (Bornstein et al., 1984; Yang et al., 2013), with abdominal 
fat pad being an accurate indicator of overall fat accumulation in all chickens (Sato et al., 2009). In broiler breeders, hens that had not entered lay prior to 55 woa had a fat pad which was $1.5 \%$ of their body weight, while those that entered lay had a fat pad of $2.5 \%$, suggesting that a minimum threshold does exist (van der Klein et al., 2018). Conversely, a study using broiler breeder hens selected for divergent abdominal body fat percentage, referred to as lean and fat hens, demonstrated that lean birds showed an earlier AFE when compared to the fat females, with an overall greater egg production (Zhang et al., 2018), supporting the necessity to avoid excessively exceeding the threshold of body fat percentage of the hen around the time of sexual maturity. Interestingly, these lean and fat hens did not statistically differ in body weight at any time (Zhang et al., 2018). Achieving a critical threshold of body composition during the juvenile stage thus appears required to support the demands for egg formation throughout a laying cycle. Seasonal migratory breeders are believed to possess a sliding body weight set point, referred to as rheostasis, defined as the body weight differences between physiological periods of breeding and migration (Mrosovsky, 1990). Body weight of a common seasonal breeder, the American Kestrel, was maintained at a significantly lower weight throughout the year as long as the hen remains in a non-breeding condition. Interestingly, prior to the breeding period, the non-breeding females in in this study were found to have a lower body weight than those that later entered lay, suggesting the need for an adequate body weight prior to the breeding season to initiate lay. Once they enter a period of breeding, body weight further increased corresponding to the week of and prior to each ovulation, with significant correlations between body weight and concentrations of the sex steroids, estradiol and estrone, attributed to a combination of alterations in fat and protein deposition, along with the maturation of the reproductive tract (Rehder et al., 1986). This suggests various weight set points may be required throughout a reproductive cycle.

Regulation of body weight and body composition is a very complex process that involves many factors and hormones, some which are also known for their role in the control of reproduction. Although the list is quite exhaustive, for the purpose of this review emphasis will be put on growth hormone $(\mathrm{GH})$ for its involvement in growth and general metabolism, PPAR- $\gamma$, adiponectin, and LEP as these hormones and factors specifically control lipid metabolism (Figure 2).

\section{Peroxisome Proliferator-Activated Receptor Gamma (PPAR- $\gamma$ )}

Peroxisome Proliferator-activated Receptor Gamma is an important regulator of lipogenesis and adipogenesis in mammals (Luquet et al., 2004). PPAR- $\gamma$ is a member of the nuclear hormone receptor superfamily, binding to the peroxisome proliferator-response element, located in the promotor region of genes directly associated with glucose, and lipid homeostasis (Straus and Glass, 2001). It is highly expressed in all pituitary secretory cells in humans (Bogazzi et al., 2005), as well as adipose tissue of broilers where it plays a major role on fat deposition
(Meng et al., 2005; Wang et al., 2008; Zhang et al., 2015). In fact, as this factor is associated specifically with the differentiation of adipocytes and lipid accumulation, it has been linked to NPY which is itself involved in the synthesis of preadipocytes in chicken adipose tissue in vitro (Zhang et al., 2015; Shipp et al., 2016). Thus, these studies suggest that PPAR- $\gamma$ may be a link between the regulation of appetite and body composition. Additionally, elevated expression of this transcription factor has been observed in the liver of broilers selected for fatness in comparison to lean birds (Larkina et al., 2011; Zhang et al., 2015), further demonstrating the ability of this factor to divert nutrients to adipose deposition. Interestingly, variations in PPAR- $\gamma$ levels have also been associated with genotype, age, and sex (Meng et al., 2005; Sato et al., 2009). In the laying hen, PPAR- $\gamma$ has been detected in various tissues including the brain, liver and ovary (Sato et al., 2004; Meng et al., 2005; Hojo et al., 2006; Ojano-Dirain et al., 2007; Wang et al., 2012), suggesting a possible role in the control of reproduction. A 23-fold increase in PPAR- $\gamma$ mRNA was observed in the liver of layers administered high doses of exogenous $\mathrm{E}_{2}$ (Lee et al., 2010). This was associated with a corresponding increase in fatty acids, triacylglycerol, and an accumulation of hepatic lipids (Sato et al., 2009; Lee et al., 2010), thus implicating PPAR- $\gamma$ in the formation of yolk precursors in the liver, an organ under the control of $E_{2}$ (Deeley et al., 1975). If PPAR- $\gamma$ upregulates the expression of MRAP, as previously discussed, this would suggest that $\mathrm{E}_{2}$, through its ability to directly trigger the upregulation of PPAR- $\gamma$, has the ability to activate the melanocortin system, diverting energy expenditure from growth to reproduction, linking sex steroids, and energy homeostasis. As a matter of fact, this has also led to the hypothesis that PPAR- $\gamma$ may play a role in the control of egg production overall, as demonstrated through higher expression levels in high producing laying hens compared to low producing lines (Chen et al., 2010). Beyond egg formation, PPAR- $\gamma$ has also been suggested to play a role in the control of gonadotropins, with one study hypothesizing that chicken prostaglandin-D synthase protein has the ability to regulate LH- $\beta$ transcription via PPAR signaling pathways (Chen et al., 2010). Whether this is a direct or indirect effect is not known.

\section{Adiponectin}

Adiponectin is a cytokine predominantly secreted by the adipose tissue with a significant role in lipid and carbohydrate metabolism in mammals (Kadowaki and Yamauchi, 2005). In addition to the breakdown of fatty acids, adiponectin increases insulin sensitivity in mice (Yamauchi et al., 2002), with involvements in energy balance and body weight (Fruebis et al., 2001; Yamauchi et al., 2001). In the chicken, while adiponectin is highly expressed in adipose tissue, it is also expressed in the liver, anterior pituitary, hypothalamus, kidney, skeletal muscle, and ovary (Maddineni et al., 2005; Chabrolle et al., 2007). Plasma concentrations of adiponectin have been shown to decline in broiler chicks between 4 to 8 woa, corresponding to an increase in body weight and a 2 -fold increase in abdominal fat pad during this time (Maddineni et al., 2005). While a decline in plasma adiponectin was not observed in birds fasted for $48 \mathrm{~h}$ (Hendricks et al., 2009), mRNA levels were found to significantly 


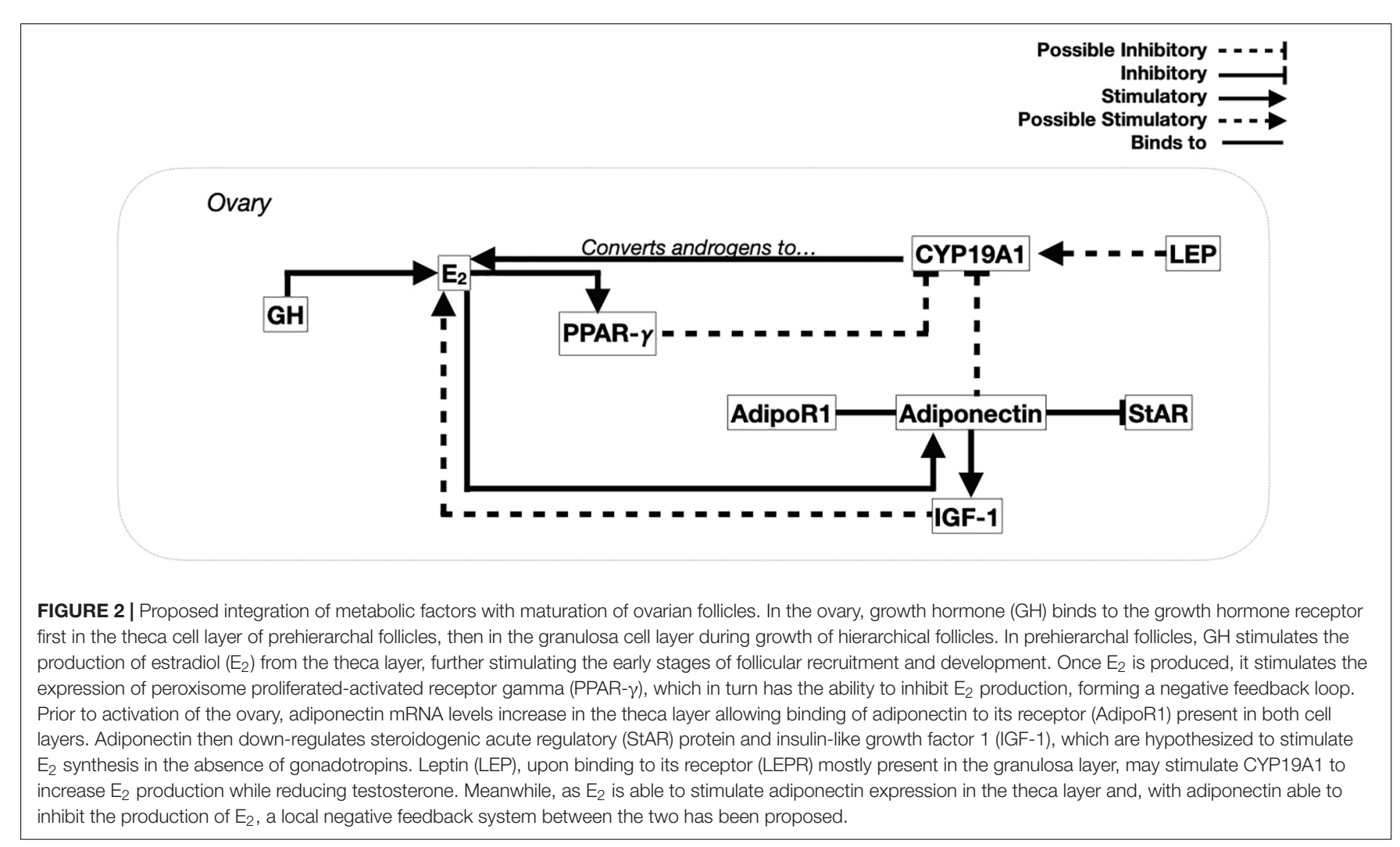

decline in adipose, liver and anterior pituitary, with other tissues, such as the hypothalamus, remaining unaffected (Maddineni et al., 2005). This implies that while expression may be altered, temporary metabolic changes have little to no influence over the short-term secretion of this hormone. Adiponectin is able to elicit its response through two receptors, AdipoR1 and AdipoR2. While AdipoR1 is primarily found in the skeletal muscle, adipose tissue and diencephalon, AdipoR2 was largely localized to the adipose tissue (Ramachandran et al., 2007), with mRNA and protein of both receptors recently found in theca and granulosa layers of ovarian follicles (Hadley et al., 2020). Signaling pathways are predicted to differ between receptors as AdipoR1 activates AMPK signaling, while AdipoR2 is believed to elicit its response through the transcription factor PPAR- $\alpha$ (Yamauchi et al., 2003). Regarding appetite control, in rodents adiponectin elicited an anorexigenic response through AdipoR1 and its co-localization with the leptin receptor (LEPR) in the hypothalamus, with both receptors present in NPY and POMC neurons (Guillod-Maximin et al., 2009). A similar relationship between AdipoR1 and LEPR should be investigated in avian species to determine the role of adiponectin and leptin in lipid metabolism and overall energy homeostasis within the hypothalamus. Additionally, the possibility of AdipoR1 and AdipoR2 being involved in a permissive, and/or inhibitory role with NPY and POMC should be explored in the hen, as there is the potential for integration with the melanocortin system, as discussed previously in regard to PPAR- $\gamma$. Meanwhile, AdipoR1 was upregulated by PRL, while AdipoR2 was downregulated by GH in adipose tissue of mice, (Nilsson et al., 2005), with both hormones inversely associated with adiponectin expression in both mice (Berryman et al., 2004), and humans (Mantzoros et al., 2004). Due to the critical role of these opposing hormones during the reproductive cycle of the hen, further studies should be conducted to determine a possible relationship in chickens. As reported in humans (Yamauchi et al., 2001), plasma adiponectin is negatively correlated to glycaemia in turkey hens (Diot et al., 2015), demonstrating a potential role in elevating insulin sensitivity. In the presence of elevated insulin concentrations, POMC and CART expression has been reported to elevate, while the expression of NPY is inhibited (Porte et al., 2002; Honda et al., 2007; Shiraishi et al., 2008). This is of particular interest as POMC has been found to increase in incubating Silkie hens, a period known to be associated with high PRL levels, compared to their laying counterparts (Sharp et al., 1989; Dawson, 2008; Takeda and Ohkubo, 2019). As AdipoR1 is upregulated in the presence of PRL, it would be expected that adiponectin levels would elevate during this period, yet concentrations have been observed to decline through to the end of production in turkey hens (Diot et al., 2015), requiring further investigation to determine its role throughout a production cycle.

Adiponectin is expressed exclusively in the theca layer of ovarian follicles within both broiler breeder and laying hens, with an autocrine or paracrine effect on steroidogenesis (Chabrolle et al., 2007; Hadley et al., 2020). Interestingly, in vitro treatment of porcine granulosa cells with recombinant adiponectin was found to increase steroidogenic acute regulatory protein (StAR) mRNA, along with a reduction in cytochrome $\mathrm{P}_{450}$ aromatase, or CYP19A1 (Ledoux et al., 2006). While StAR is responsible 
for transporting cholesterol across the inner mitochondrial membrane in order to undergo conversion to pregnenolone (Sugawara et al., 1995; Cherradi et al., 1997), CYP19A1 converts testosterone to $\mathrm{E}_{2}$. Altogether, this implies that regardless of the ability of adiponectin to stimulate StAR, the decline in CYP19A1 would inhibit the synthesis of $E_{2}$. Recently, granulosa cells from subsets of prehierarchal and preovulatory follicles of broiler breeder and laying hens cultured with recombinant adiponectin reported a decline in StAR mRNA abundance in all follicle groups, with the exception of F4 (Hadley et al., 2020). Additionally, the AMPK signalling pathway has been determined to be activated by adiponectin in the chicken. This AMPK pathway has been shown to differentially regulate StAR depending on the stage of follicular development (Tosca et al., 2006), suggesting that the unequivocal expression of StAR in response to adiponectin in vitro can be influenced by a variety of factors and requires further investigation. Furthermore, activation of this pathway led to an increased production of $\mathrm{P}_{4}$, along with an elevation in StAR and CYP19A1 levels, in the absence of FSH (Tosca et al., 2006), indicating that another factor may be able to overcome the need for gonadotropin stimulation in avian species. When human recombinant adiponectin was applied to chicken granulosa cells from pre-ovulatory follicles for $36 \mathrm{~h}$ in culture, the expression of insulin-like growth factor1 (IGF-1)-induced $\mathrm{P}_{4}$ secretion in preovulatory follicles was upregulated, while $\mathrm{LH}$ and $\mathrm{FSH}$-induced $\mathrm{P}_{4}$ production in this same subset of follicles decreased (Chabrolle et al., 2007). This further supports the hypothesis that adiponectin is able to influence steroidogenesis within the follicular hierarchy of the chicken ovary, regardless of the status of the HPG axis. Thus, we hypothesize that adiponectin provides a mechanism through which metabolism is able to overcome the need for photostimulation during the activation of the ovary, via the stimulation of IGF-1 induced $\mathrm{P}_{4}$ production. Further supporting the link between adiponectin and reproduction, a recent broiler breeder study showed the timing of an $\mathrm{E}_{2}$ increase corresponded to the time during which adiponectin declined in the circulating plasma (Grandhaye et al., 2019). However, when sexually immature leghorn chickens were treated with $\mathrm{E}_{2}$, adiponectin mRNA abundance was found to be elevated, along with the mRNA levels of AdipoR1, while $\mathrm{P}_{4}$ treatment caused a decline in adiponectin mRNA (Hadley et al., 2020). In Huoyan geese, when ovarian granulosa cells were treated with adiponectin, a significant decline was observed in $\mathrm{E}_{2}$, while $\mathrm{P}_{4}$ concentration increased (Meng et al., 2019). This suggests an overall negative feedback system between adiponectin and the reproductive steroids. Furthermore, plasma adiponectin did not vary during the laying cycle, with a significant decline only found in turkey hens at the end of lay (Diot et al., 2015). Altogether, this indicates that another mechanism is utilized in order to select follicles into the preovulatory hierarchy. As adiponectin contributes to the downregulation of fat deposition (Hendricks et al., 2009; Tahmoorespur et al., 2010), which aligns with the decreased body fat percentage observed in the current commercial broiler breeder (Zuidhof et al., 2014), it is possible that these hens have elevated adiponectin levels, which may be influenced by its high mRNA expression in the liver and anterior pituitary
(Maddineni et al., 2005). This would lead to the hypothesis that adiponectin is able to act in the ovary to promote IGF1 induced $\mathrm{P}_{4}$, rather than $\mathrm{LH}$ or FSH-induced $\mathrm{P}_{4}$. This level of control must be considered to determine the effects of body weight and metabolic status on follicular development and age of first egg.

\section{Growth Hormone (GH)}

Growth hormone is produced primarily by the anterior pituitary gland under the control of hypothalamic growth hormone releasing hormone $(\mathrm{GHRH})$, with additional production in a multitude of other tissues in addition to the hypothalamus (Render et al., 1995). Although initially identified as a purely somatic hormone promoting growth, a reproductive function for $\mathrm{GH}$ has been proposed as plasma levels correlate with the onset of lay in pullets (Williams et al., 1992), and the time of ovulation in hens (Harvey et al., 1979b). Injections of $\mathrm{GH}$ in immature laying hens increased ovary weight 1 week prior to maturation (Hrabia et al., 2011). However, for this to happen, it is critical that the growth hormone receptor (GH-R) be expressed within the follicles (Lebedeva et al., 2004; Hrabia et al., 2008) at that time. As GH-R expression increases in the ovary around the time of sexual maturation (Hrabia et al., 2008), it can be predicted that a similar $\mathrm{GH}$ effect on ovarian follicles would not occur at an earlier age. However, administration of GH increased the number of SWF (Williams et al., 1992), which not only serve as the follicular pool for the remainder of lay, but are also responsible for the production of $\mathrm{E}_{2}$ during sexual maturation (Robinson and Etches, 1986). While GH further stimulated the release of $\mathrm{E}_{2}$ from the pre-hierarchal follicles (Hrabia et al., 2012), a decline in this steroid hormone occurred within the hierarchy (Hrabia et al., 2014). A relationship between $\mathrm{E}_{2}$ and $\mathrm{GH}$ can also be seen in the liver, which is responsive to both hormones (Stevens, 2007; Van Anes et al., 2010). GH has been linked to the elevated expression of estrogen receptor beta (ER- $\beta$ ) in the liver (Hrabia, 2015), suggesting an influence of GH on vitellogenesis, as demonstrated in the pigeon (Harvey et al., 1978). Interestingly, white leghorn laying hens with the sexlinked dwarf gene $(d w)$ have been found to demonstrate a dysfunction in the GH-R gene, with a missense mutation found in the cDNA (Hull et al., 1993, 1999), reducing the GHbinding activity in the serum and liver without a complete inhibition (Hull et al., 1999). While this mutation does not appear to affect the production rate of heavy type chickens, this $\mathrm{dw}$ gene was found to reduce the laying rate of medium and light strains by up to $10 \%$ (Guillaume, 1976). Furthermore, these dwarf hens have been determined to be abnormally fat, with a declined ability to mobilize adipose tissue during lay (Guillaume, 1976; Burghelle-Mayeur et al., 1989), suggesting a role for body fat percentage in the ability to maintain high production rates.

At the end of the laying cycle, decreasing GH concentrations have been reported in many avian species (Scanes et al., 1979; Sharp et al., 1979; Bedrak et al., 1981). Thus, it is evident that $\mathrm{GH}$ has the ability to control reproduction at the level of the gonads. However, further evidence also supports an effect higher 
up in the HPG axis as GH-containing neurons are located throughout the hypothalamus of both turkey hens and ring doves, specifically in the PVN, IN, and ME (Ramesh et al., 2000), as well as the MBH in Japanese quail (Berghman et al., 1992), with expression patterns similar to PRL-containing neurons (Ramesh et al., 2000). Thus, similar to the pituitary, GH and PRL dynamics are linked in the hypothalamus. In the pituitary gland of turkey hens during the transition from egg laying to expression of incubation behaviour, PRL cells replace GH cells, as PRL becomes the predominant circulating hormone associated with the cessation of lay (Ramesh et al., 1996). As the hen begins to drop out of production, PRL expression in the avian brain increased (Ramesh et al., 1996), with a corresponding decline in GnRH (Saldanha et al., 1994).

\section{Leptin (LEP)}

After decades of controversy, erroneous publications (Taouis et al., 1998; Ashwell et al., 1999), and hypotheses regarding its existence (Dakovic et al., 2014), the chicken LEP gene was recently discovered embedded in a GC-rich portion of the genome with numerous repeated segments (Seroussi et al., 2016). Unlike in mammals, where LEP is predominantly produced by adipose tissue, gene expression profiles in the chicken show moderate to high LEP mRNA levels in the cerebellum, hypothalamus, cerebrum, adrenal glands, embryonic testis and ovary, along with low levels in adipose tissue, kidney, and heart. Interestingly, expression of its receptor LEPR correlated with $86 \%$ of all tissues in which LEP was discovered. This led to the hypothesis that in the chicken, LEP acts mostly in an autocrine, and/or paracrine fashion (Seroussi et al., 2016), rather than the endocrine response observed in mammals (Kershaw and Flier, 2004). This is further supported by the low levels of circulating LEP found in serum (Seroussi et al., 2016). One of the obvious differences between mammalian and avian profiles is the strong gene expression in the pituitary of the hen, while the hypothalamus is the primary site in mammals, suggesting a potential shift in control of homeostasis by this hormone (Dunn et al., 2000; Seroussi et al., 2016). Nonetheless, due to minimal expression detected in adipose and liver tissues in chickens, evidence suggests LEP may not play a role in avian appetite control (Seroussi et al., 2016). Therefore, further investigation is required to determine the stimulatory pathway of this hormone.

As the gene encoding chicken LEP remained elusive despite the characterization of its receptor, most studies conducted in avian species relied on administration of mammalian LEP. LEP signaling was implicated in a number of processes in the domestic chicken, including glucose and insulin activity (Kamohara et al., 1997; German et al., 2009; Huo et al., 2009), with hyperglycemia downregulating LEPR and insulin receptor (INSR; Rancourt et al., 2015). LEP also interacts with the melanocortin system, through POMC/CART and NPY/AgRP neurons (Elias et al., 1998; Davidowa and Plagemann, 2000; Cowley et al., 2001; Nagamori et al., 2003; Takahashi and Cone, 2005). In rats, LEP led to a significant decrease in hypothalamic NPY expression (Schwartz et al., 1996) through the inhibition of NPY and AgRP neurons (Davidowa and Plagemann, 2000; Nagamori et al., 2003; Takahashi and Cone, 2005), while stimulating POMC and CART neurons (Elias et al., 1998; Cowley et al., 2001), thus classifying LEP as an anorexigenic hormone (Balthasar et al., 2004; Williams et al., 2009; Yosefi et al., 2010). However, the anorexigenic effect of LEP may depend on breed or age in chickens, as it had no impact on feed intake in broiler chicks (Sims et al., 2017), although it could increase body weight post-hatch, as well as average daily gain with high doses, while LEP antagonists reversed these effects (Yuan et al., 2017). One rationale for the proposed control of the melanocortin system by LEP is its high level of expression in the brain with undetectable levels in the systemic circulation (Yosefi et al., 2010; Seroussi et al., 2016). In contrast, mammalian LEP is highly expressed in adipose tissue resulting in significant circulating levels, using a short form of LEPR to facilitate its transport across the blood brain barrier (Tartaglia, 1997). In avian species, this short form LEPR is absent (Liu et al., 2007) and LEP exerts its actions by binding to the long form LEPR, activating the JAK-STAT pathway (Adachi et al., 2008; Prokop et al., 2014).

Unfortunately, far less information on a potential role of LEP on the reproductive axis is available in chickens. A study conducted on commercial broiler breeders fed ad libitum showed that expression of LEPR was greatest in the granulosa cells of the F3 and F4 follicles, though feed restriction significantly decreased mRNA levels. No differences in relative expression of LEPR within the theca layers of these follicles were reported. Interestingly, LEPR gene expression in the liver was significantly increased in hens fed ad libitum compared with feed restricted broiler breeders (Shi et al., 2006). In the laying hen, immunoneutralization of LEP reduced the rate of egg production (Shi et al., 2006), while LEP treatment advanced sexual maturation and ovarian folliculogenesis (PaczoskaEliasiewicz et al., 2003, 2006). This reported earlier onset of lay was shown to occur through the stimulation of $\mathrm{LH}$, as well as $\mathrm{E}_{2}$ and $\mathrm{P}_{4}$ production (Paczoska-Eliasiewicz et al., 2006), although a decline in testosterone induced by LEP treatment may result from elevated conversion rate into $\mathrm{E}_{2}$ (Sirotkin and Grossmann, 2007). Interestingly, LEP inhibited apoptosis, as indicated by the reduced expression of apoptotic markers within the ovary, along with the promotion of steroidogenesis and differentiation, supporting follicular development (Sirotkin and Grossmann, 2007). Recent studies have also shown that chicken LEP increases the firing rate of neurons within the IN (Bogatyrev et al., 2017), while reducing the expression of the glucocorticoid receptor in the brain (Yuan et al., 2017). This suggests that LEP has the ability to influence signalling within this region of the brain.

\section{CONCLUSION}

Through divergent breeding goals, selection programs for broiler chickens have largely focussed on rapid offspring growth rate, resulting in poor reproductive efficiency of breeders (van der Klein et al., 2020). In contrast, laying hen selection was 
primarily based on egg output, with commercial layers more than doubling production over the last 50 years. Through this review, we emphasized that the photoperiodic and metabolic responses utilize many factors that share common pathways and mechanisms to control sexual maturation at all levels of the HPG axis in layer chickens. Although OPN4, OPN5, and VA-Opsin, have all been proposed as deep-brain photoreceptors mediating the photoperiodic response (Foster et al., 1985, 1994; Chaurasia et al., 2005; Halford et al., 2009; Kang et al., 2010; Nakane and Yoshimura, 2010; Davies et al., 2012; Ohuchi et al., 2012), VAOpsin is the only photoreceptor that has been found to meet all four criteria outlining the activity of the opsin of interest $(68,69,71,101$; Table 1). In particular, recent evidence of the co-expression of VA-Opsin and GnRH-I strongly suggests this DBP may be a key photoreceptor involved in the photo-induced activation of the HPG axis (García-Fernández et al., 2015).

Beyond photoperiod, it has become clear that sexual maturation can occur prior to photostimulation when a body composition threshold has been met in both layers and broiler breeders (van der Klein et al., 2018; Baxter and Bédécarrats, 2019). Thus, growth is intimately linked to and can influence the initiation of reproduction at the hypothalamic level, and possibly at the level of the ovary. Current knowledge suggests the melanocortin system is strongly associated with the expression of neuropeptides from the HPG axis, with GnIH stimulating the orexigenic peptides AgRP and NPY, while inhibiting the anorexigenic peptides POMC and CART (McConn et al., 2014), as seen in Figure 1. While GnIH downregulates the expression of $\mathrm{GnRH}$, we also hypothesize that elevated expression of AgRP and NPY activate it, thereby allowing the metabolic factors to activate the HPG axis (Contijoch et al., 1993), yet the close proximity of NPY and VIP perikarya in the IN and dorsomedial hypothalamus (DMH) in the redheaded bunting cannot be overlooked (Surbhi et al., 2016). VIP is known to participate in the perception of photoperiod and this close relationship with NPY neurons maybe the key to link metabolism, reproduction and photoperiod (Silver et al., 1988; Bi, 2007; Rastogi et al., 2013; Surbhi et al., 2016) via interaction with GnRH-I and GnIH neurons (Surbhi et al., 2015). Once sexually mature, higher $\mathrm{GnRH}$ production results in increased steroidogenesis stimulating POMC and CART expression, thus decreasing feed intake. While CART and $\alpha-\mathrm{MSH}$ are hypothesized to positively feedback on GnRH, ACTH stimulates AgRP and NPY (Mountjoy et al., 1994; Kawakami et al., 2000; Strader et al., 2003; Cline et al., 2008; Shipp et al., 2016). However, $\beta$-endorphin inhibits LH release (Sakurai et al., 1986; Stansfield and Cunningham, 1987), highlighting the importance of the cleavage of POMC. Interestingly, a recent study reported increased AgRP and NPY mRNA levels with decreased POMC and CART mRNA

\section{REFERENCES}

Adachi, H., Takemoto, Y., Bungo, T., and Ohkubo, T. (2008). Chicken leptin receptor is functional in activating JAK-STAT pathway in vitro. J. Endocrinol. 197, 335-342. doi: 10.1677/joe-08-0098

Aguilera, G. (1994). Regulation of Pituitary ACTH secretion during chronic stress. Front. Neuroendocrinol. 15:321-350. doi: 10.1006/frne.1994.1013 levels in photosensitive roosters, while the opposite gene expression patterns were observed in photorefractory birds (Stevenson and Ball, 2012).

At the level of the ovary, as shown in Figure 2, additional factors involved in body composition, such as PPAR- $\gamma, \mathrm{GH}$, and adiponectin, have the ability to stimulate the maturation and maintenance of the hierarchy. With adiponectin increasing IGF-1-stimulated $\mathrm{P}_{4}$ production (Chabrolle et al., 2007), it is hypothesized that this hormone can activate the hierarchical development of ovarian follicles prior to activation of the upper levels of the HPG-axis. Interestingly, GH was found to stimulate $\mathrm{E}_{2}$ synthesis (Hrabia et al., 2012), which in turn increases the expression of PPAR- $\gamma$ (Lee et al., 2010). Contrary to mammals, it has been suggested that LEP plays an autocrine/paracrine role at all levels of the reproductive axis in chickens, including the ovary (Seroussi et al., 2016) where it may participate in the maturation of the follicular hierarchy, yet the stimulatory influence on this hormone remains unidentified.

While a number of unanswered questions remain, this review highlights that photostimulation is not the only cue involved in the activation of the reproductive axis in chickens. Metabolic status and/or thresholds can transcend photoperiodic responses. The evidence presented here suggests that although these pathways can act independently, they are in fact synergistic and a coordinated response may optimize reproduction.

\section{AUTHOR CONTRIBUTIONS}

$\mathrm{CH}$ was the primary writer and performed most of the literature search. RR contributed to the section on the reproductive axis as well as the section on metabolic control (specifically the "Additional Factors Involved in the Orexigenic Response with Potential Roles in Reproduction" section). MZ contributed to the metabolism section in particular with insights into practical application and significance. GB participated in the redaction of all sections and supported $\mathrm{CH}$ throughout the project as Ph.D. supervisor. All authors contributed to the article and approved the submitted version.

\section{FUNDING}

This review was in part supported by funding from the Canada First Research Excellence Fund (Food from Thought Agricultural Systems for a Healthy Planet), the Livestock Research Innovation Corporation and the Poultry Industry Council (Project \#331), and the Natural Sciences and Engineering Research Council of Canada (Discovery program). 
Ashwell, C. M., Czerwinski, S. M., Brocht, D. M., and McMurtry, J. P. (1999). Hormonal regulation of leptin expression in broiler chickens. Am. J. Physiol. 45, R226-R232.

Bailey, M. J., and Cassone, V. M. (2005). Melanopsin expression in the chick retina and pineal gland. Mol. Brain Res. 134, 345-348. doi: 10.1016/j.molbrainres. 2004.11.003

Bain, M. M., Nys, Y., and Dunn, I. C. (2016). Increasing persistency in lay and stabilising egg quality in longer laying cycles. What are the challenges? Br. Poult. Sci. 57, 330-338. doi: 10.1080/00071668.2016.1161727

Balthasar, N., Coppari, R., McMinn, J., Liu, S. M., Lee, C. E., Tang, V., et al. (2004). Leptin receptor signaling in POMC neurons is required for normal body weight homeostasis. Neuron 42, 983-991. doi: 10.1016/j.neuron.2004.06.004

Banerjee, S., and Chaturvedi, C. M. (2018). Neuroendocrine mechanism of food intake and energy regulation in Japanese quail under differential simulated photoperiodic conditions: involvement of hypothalamic neuropeptides, AMPK, insulin and adiponectin receptors. J. Photochem. Photobiol. B Biol. 185, 10-23. doi: 10.1016/j.jphotobiol.2018.05.020

Banerjee, S., Shahin, S., and Chaturvedi, C. M. (2018). Age dependent variations in the deep brain photoreceptors (DBPs), GnRH- GnIH system and testicular steroidogenesis in Japanese quail, Coturnix coturnix japonica. Exp. Gerontol. 108, 7-17. doi: 10.1016/j.exger.2018.03.018

Baxter, M., and Bédécarrats, G. Y. (2019). Evaluation of the impact of light source on reproductive parameters in laying hens housed in individual cages. J. Poult. Sci. 56, 148-158. doi: 10.2141/jpsa.0180054

Baxter, M., Joseph, N., Osborne, V. R., and Bédécarrats, G. Y. (2014). Red light is necessary to activate the reproductive axis in chickens independently of the retina of the eye. Poult. Sci. 93, 1289-1297. doi: 10.3382/ps.2013-03799

Bédécarrats, G. Y. (2015). Control of the reproductive axis: balancing act between stimulatory and inhibitory inputs. Poult. Sci. 94, 810-815. doi: 10.3382/ps/ peu042

Bedecarrats, G. Y., Baxter, M., and Sparling, B. (2016). An updated model to describe the neuroendocrine control of reproduction in chickens. Gen. Comp. Endocrinol. 227, 58-63. doi: 10.1016/j.ygcen.2015.09.023

Bédécarrats, G. Y., McFarlane, H., Maddineni, S. R., and Ramachandran, R. (2009). Gonadotropin-inhibitory hormone receptor signaling and its impact on reproduction in chickens. Gen. Comp. Endocrinol. 163, 7-11. doi: 10.1016/j. ygcen.2009.03.010

Bedrak, E., Harvey, S., and Chadwick, A. (1981). Concentrations of pituitary, gonadal and adrenal hormones in serum of laying and broody white rock hens (Gallus domesticus). J. Endocrinol. 89, 197-204. doi: 10.1677/joe.0.0890197

Bellingham, J., Chaurasia, S. S., Melyan, Z., Liu, C., Cameron, M. A., and Tarttelin, E. E. (2006). Evolution of melanopsin photoreceptors: discovery and characterization of a new melanopsin in nonmammalian vertebrates. PLoS Biol. 4:1334-1343.

Benoit, J. (1935a). Le role des yeux dans l'action stimulate de la lumiere sure le development testiculaire chez le canard. CR Soc. Biol. 118, 669-671.

Benoit, J. (1935b). Stimulation par la lumiere artificielle du development testiculaire chez des canards aveugles par section du neuf optique (avec demonstrations). CR Soc. Biol. 120, 133-136.

Bentley, G. E., Perfito, N., Ukena, K., Tsutsui, K., and Wingfield, J. C. (2003). Gonadotropin-inhibitory peptide in song sparrows (Melospiza melodia) in different reproductive conditions, and in house sparrows (Passer domesticus) relative to chicken-gonadotropin-releasing hormone. J. Neuroendocrinol. 15, 794-802. doi: 10.1046/j.1365-2826.2003.01062.x

Bentley, G. E., Tucker, S., Chou, H., Hau, M., and Perfito, N. (2013). Testicular growth and regression are not correlated With Dio2 expression in a wild male songbird, sturnus vulgaris, exposed to natural changes in photoperiod. Endocrinology 154, 1813-1819. doi: 10.1210/en.2013-1093

Bentley, G. E., Ubuka, T., McGuire, N. L., Chowdhury, V. S., Morita, Y., and Yano, T. (2008). Gonadotropin-inhibitory hormone and its receptor in the avian reproductive system. Gen. Comp. Endocrinol. 156, 34-43. doi: 10.1016/j.ygcen. 2007.10.003

Berghman, L. R., Devreese, B., Verhaert, P., Gerets, H., Arckens, L., and Vanden Broeck, J. (1998). The molecular characterisation of chicken pituitary N-terminal pro-opiomelanocortin (POMC). Mol. Cell. Endocrinol. 142, 119130. doi: 10.1016/s0303-7207(98)00112-9

Berghman, L. R., Grauwels, L., Vanhamme, L., Proudman, J. A., Foidart, A., Balthazart, J., et al. (1992). Immunocytochemistry and immunoblotting of avian prolactins using polyclonal and monoclonal antibodies toward a synthetic fragment of chicken prolactin. Gen. Comp. Endocrinol. 85, 346-357. doi: 10. 1016/0016-6480(92)90079-y

Bernal, J. (2002). Action of thyroid hormone in brain. J. Endocrinol. Invest. 25, 268-288.

Berryman, D. E., List, E. O., Coschigano, K. T., Behar, K., Kim, J. K., and Kopchick, J. J. (2004). Comparing adiposity profiles in three mouse models with altered GH signaling. Growth Horm. IGF Res. 14, 309-318. doi: 10.1016/j.ghir.2004.0 2.005

Bhatt, R., Youngren, O., Kang, S., and El Halawani, M. (2003). Dopamine infusion into the third ventricle increases gene expression of hypothalamic vasoactive intestinal peptide and pituitary prolactin and luteinizing hormone $\beta$ subunit in the turkey. Gen. Comp. Endocrinol. 130, 41-47. doi: 10.1016/s0016-6480(02) 00533-6

$\mathrm{Bi}$, S. (2007). Role of dorsomedial hypothalamic neuropeptide $\mathrm{Y}$ in energy homeostasis. Peptides 28, 352-356. doi: 10.1016/j.peptides.2006.07.030

Bogatyrev, S., Yakimova, K., and Tzschentke, B. (2017). Influence of leptin and - GABAB-receptor agonist and antagonist on neurons of the hypothalamic infundibular nucleus in the chicken. J. Comp. Physiol. A 203, 291-299.

Bogazzi, F., Russo, D., Locci, M., Chifenti, B., Ultimieri, F., Raggi, F., et al. (2005). Peroxisome proliferator-activated receptor (PPAR-gamma) is highly expressed in normal human pituitary gland. J. Endocrinol. Invest. 28, 899-904. doi: 10.1007/bf03345321

Bornstein, S., Plavnik, I., and Lev, Y. (1984). Body weight and/or fatness as potential determinants of the onset of egg production in broiler breeder hens. Br. Poult. Sci. 25, 323-341. doi: 10.1080/00071668408454873

Boswell, T. (2011). "Regulation of feeding by neuropeptide Y," in Avian Endocrinology, eds A. Dawson, and C. Chaturvedi (New Delhi: Narosa Publishing House), 349-360.

Boswell, T., Li, Q., and Takeuchi, S. (2002). Neurons expressing neuropeptide $\mathrm{Y}$ mRNA in the infundibular hypothalamus of Japanese quail are activated by fasting and co-express agouti-related protein mRNA. Mol. Brain Res. 100, 31-42. doi: 10.1016/s0169-328x(02)00145-6

Boswell, T., and Takeuchi, S. (2005). Recent developments in our understanding of the avian melanocortin system: Its involvement in the regulation of pigmentation and energy homeostasis. Peptides 26, 1733-1743. doi: 10.1016/ j.peptides.2004.11.039

Bowmaker, J., and Knowles, A. (1977). The visual pigments and oil the Chicken Retina. Vision Res. 17, 755-764. doi: 10.1016/0042-6989(77)90117-1

Brewer, C. J., and Balen, A. H. (2010). The adverse effects of obesity on conception and implantation. Reproduction 140, 347-364. doi: 10.1530/rep-09-0568

Brody, T. B., Siegel, P. B., and Cherry, J. A. (1984). Age, body weight and body composition requirements for the onset of sexual maturity of dwarf and normal chickens. Br. Poult. Sci. 25, 245-252. doi: 10.1080/0007166840845 4863

Burghelle-Mayeur, C., Tixier-Boichard, M., Merat, P., and Demarne, Y. (1989). De novo lipogenesis and lipolysis activities in normal (Dw) and dwarf (dw) white leghorn laying hens. Comp. Biochem. Physiol. Part B Biochem. 93, 773-779. doi: 10.1016/0305-0491(89)90044-8

Burke, W. H., Papkoff, H., Licht, P., and Gallo, A. B. (1979). Preparation and Properties of Luteinizing Hormone (LH) Subunits from the Turkey (Meleagris gallopavo) and their Recombination with Subunits of Ovine LH. Gen. Comp. Endocrinol. 37, 501-507. doi: 10.1016/0016-6480(79)90032-7

Byerly, T., and Moore, O. (1941). Clutch length in relation to period of illumination in the domestic fowl. Poult. Sci. 20, 387-390. doi: 10.3382/ps.0200387

Cai, G., Mo, C., Huang, L., Li, J., and Wang, Y. (2015). Characterization of the two CART genes (CART1 and CART2) in chickens (Gallus gallus). PLoS One 10:e0127107. doi: 10.1371/journal.pone.0127107

Calvo, F., and Bahr, J. (1983). Adenylyl cyclase system of the small preovulatory hormone follicles of the domestic hen : responsiveness to follicle-stimulating and luteinizing hormone. Biol. Reprod. 29, 542-547. doi: 10.1095/biolreprod29. 3.542

Chabrolle, C., Tosca, L., Crochet, S., Tesseraud, S., and Dupont, J. (2007). Expression of adiponectin and its receptors (AdipoR1 and AdipoR2) in chicken ovary: potential role in ovarian steroidogenesis. Domest. Anim. Endocrinol. 33, 480-487. doi: 10.1016/j.domaniend.2006.08.002

Chaiseha, Y., Youngren, O., Al-Zailaie, K., and El Halawani, M. (2003). Expression of D1 and D2 dopamine receptors in the hypothalamus and pituitary during 
the turkey reproductive cycle: colocalization with vasoactive intestinal peptide. Neuroendocrinology 77, 105-118. doi: 10.1159/000068649

Chaurasia, S. S., Rollag, M. D., Jiang, G., Hayes, W. P., Haque, R., Natesan, A., et al. (2005). Molecular cloning, localization and circadian expression of chicken melanopsin (Opn4): differential regulation of expression in pineal and retinal cell types. J. Neurochem. 92, 158-170. doi: 10.1111/j.1471-4159.2004.02 874.x

Chen, L., Lee, S., Lin, Y., Hsieh, Y., Chen, Y., Yang, J., et al. (2010). Prostaglandin$\mathrm{D}$ synthetase induces transcription of the LH beta subunit in the primary culture of chicken anterior pituitary cells via the PPAR signaling pathway. Theriogenology 73, 367-382. doi: 10.1016/j.theriogenology.2009.09.020

Chen, P., Li, C., Haskell-Luevano, C., Cone, R. D., and Smith, M. S. (1999). Altered expression of agouti-related protein and its colocalization with neuropeptide $\mathrm{Y}$ in the arcuate nucleus of the hypothalamus during lactation. Endocrinology 140, 2645-2650. doi: 10.1210/endo.140.6.6829

Cherradi, N., Rossier, M. F., Vallotton, M. B., Timberg, R., Friedberg, I., and Orly, J. (1997). Submitochondrial distribution of three key steroidogenic proteins (steroidogenic acute regulatory protein and cytochrome $\mathrm{P} 450$ (scc) and $3 \beta$ - hydroxysteroid dehydrogenase isomerase enzymes) upon stimulation by intracellular calcium in adrenal glomerulosa cel. J. Biol. Chem. 272, 7899-7907. doi: $10.1074 / j b c .272 .12 .7899$

Ciccone, N., Dunn, I., Boswell, T., Tsutsui, K., Ubuka, T., Ukena, K., et al. (2004). Gonadotrophin inhibitory hormone depresses gonadotropin alpha and folliclestimulating hormone beta subunit expression in the pituitary of the domestic chicken. J. Neuroendocrinol. 16, 999-1006. doi: 10.1111/j.1365-2826.2005. 01260.x

Ciccone, N. A., Dunn, I. C., and Sharp, P. J. (2007). Increased food intake stimulates GnRH-I, glycoprotein hormone $\alpha$-subunit and follistatin mRNAs, and ovarian follicular numbers in laying broiler breeder hens. Domest. Anim. Endocrinol. 33, 62-76. doi: 10.1016/j.domaniend.2006.04.008

Clarke, I. J., Scott, C. J., Rao, A., Pompolo, S., and Barker-Gibb, M. L. (2000). Seasonal changes in the expression of neuropeptide Y and proopiomelanocortin mRNA in the arcuate nucleus of the ovariectomized ewe: relationship to the seasonal appetite and breeding cycles. J. Neuroendocrinol. 12, 1105-1111. doi: 10.1046/j.1365-2826.2000.00570.x

Cline, M. A., Prall, B. C., Smith, M. L., Calchary, W. A., and Siegel, P. B. (2008). Differential appetite-related responses to central neuropeptide $S$ in lines of chickens divergently selected for low or high body weight. J. Neuroendocrinol. 20, 904-908. doi: 10.1111/j.1365-2826.2008.01742.x

Cone, R. D. (2006). Studies on the physiological functions of the melanocortin system. Endocr. Rev. 27, 736-749. doi: 10.1210/er.2006-0034

Contijoch, A., Malamed, S., McDonald, J., and Advis, J. (1993). Neuropeptide Y regulation of LHRH release in the median eminence: immunocytochemical and physiological evidence in hens. Neuroendocrinology 57, 135-145. doi: 10.1159/ 000126353

Cowley, M. A., Smart, J. L., Rubinstein, M., Cerdán, M. G., Diano, S., Horvath, T. L., et al. (2001). Leptin activates anorexigenic POMC neurons through a neural network in the arcuate nucleus. Nature 411, 480-484. doi: 10.1038/3507 8085

Dacke, C. G., Arkle, S., Cook, D. J., Wormstone, I. M., Jones, S., Zaidi, M., et al. (1993). Medullary bone and avian calcium regulation. J. Exp. Biol. 88, 63-88.

Dakovic, N., Térézol, M., Pitel, F., Maillard, V., Elis, S., Leroux, S., et al. (2014). The loss of adipokine genes in the chicken genome and implications for insulin metabolism. Mol. Biol. Evol. 31, 2637-2646. doi: 10.1093/molbev/msu208

Davidowa, H., and Plagemann, A. (2000). Decreased inhibition by leptin of hypothalamic arcuate neurons in neonatally overfed young rats. Neuroreport 11, 2795-2798. doi: 10.1097/00001756-200008210-0 0037

Davies, S., and Deviche, P. (2014). At the crossroads of physiology and ecology: food supply and the timing of avian reproduction. Horm. Behav. 66, 41-55. doi: 10.1016/j.yhbeh.2014.04.003

Davies, W. I. L., Turton, M., Peirson, S. N., Follett, B. K., Halford, S., and Garciafernandez, J. M. (2012). Vertebrate ancient opsin photopigment spectra and the avian photoperiodic response. Biol. Lett. Neurobiol. 8, 291-294. doi: 10.1098/ rsbl.2011.0864

Dawson, A. (2008). Control of the annual cycle in birds: endocrine constraints and plasticity in response to ecological variability. Philos. Trans. R. Soc. B Biol. Sci. 363, 1621-1633. doi: 10.1098/rstb.2007.0004
Dawson, A., King, V. M., Bentley, G. E., and Ball, G. F. (2001). Photoperiodic control of seasonality in birds. J. Biol. Rhythms 16, 365-380. doi: 10.1177/ 074873001129002079

De Lanerolle, N. C., Elde, R. P., Sparber, S. B., and Frick, M. (1981). Distribution of methionine-enkephalin immunoreactivity in the chick brain: an immunohistochemical study. J. Comp. Neurol. 199, 513-533. doi: 10.1002/cne. 901990406

Decuypere, E., Bruggeman, V., Everaert, N., Li, Y., Boonen, R., and de Tavernier, J. (2010). The broiler breeder paradox: ethical, genetic and physiological perspectives, and suggestions for solutions. Br. Poult. Sci. 51, 569-579. doi: 10.1080/00071668.2010.519121

Deeley, R. G., Mullinix, K. P., Wetekam, W., Kronenberg, H., Meyers, M., and Eldridge, J. D. (1975). Vittelogenin synthesis in the avian liver. J. Biol. Chem. 250, 9060-9066.

Delp, M. S., Cline, M. A., and Gilbert, E. R. (2017). Neuroscience Letters The central effects of alpha-melanocyte stimulating hormone (alpha-MSH) in chicks involve changes in gene expression of neuropeptide $\mathrm{Y}$ and other factors in distinct hypothalamic nuclei. Neurosci. Lett. 651, 52-56. doi: 10.1016/j.neulet. 2017.04.064

Deviche, P., and Schepers, G. (1984). Intracerebroventricular injection of ostrich $\beta$-endorphin to satiated pigeons induces hyperphagia but not hyperdipsia. Peptides 5, 691-694. doi: 10.1016/0196-9781(84)90008-1

Díaz, N. M., Morera, L. P., Tempesti, T., and Guido, M. E. (2017). The visual cycle in the inner retina of chicken and the involvement of retinal G-proteincoupled receptor (RGR). Mol. Neurobiol. 54, 2507-2517. doi: 10.1007/s12035016-9830-5

Diot, M., Reverchon, M., Rame, C., Froment, P., Brillard, J. P., and Brière, S. (2015). Expression of adiponectin, chemerin and visfatin in plasma and different tissues during a laying season in turkeys. Reprod. Biol. Endocrinol. 13, 1-14.

Douglass, J. (1995). PCR differential transcriptionally. Animals 15, 2471-2481. doi: 10.1523/jneurosci.15-03-02471.1995

Dunn, I. C., Boswell, T., Eshdat, Y., Burt, W., Paton, I. R., Kollers, S., et al. (2000). Mapping of the leptin receptor gene (LEPR) to chicken chromosome 8 Physical mapping of the interleukin-7 receptor gene (IL7 R) to bovine chromosome 20q15-q17. Mol. Cell. Endocrinol. 20:252541.

Dunn, I. C., Miao, Y. W., Morris, A., Romanov, M. N., Wilson, P. W., and Waddington, D. (2004). A studyof association between genetic markers in candidate genes and reproductive traits in one generation of a commercial broiler breeder hen population. Heredity 92, 128-134. doi: 10.1038/sj.hdy. 6800396

Dunn, I. C., Wilson, P. W., D’Eath, R. B., and Boswell, T. (2015). Hypothalamic agouti-related peptide mRNA is elevated during natural and stress-induced anorexia. J. Neuroendocrinol. 27, 681-691. doi: 10.1111/jne.12295

Dunn, I. C., Wilson, P. W., Smulders, T. V., Sandilands, V., Eath, R. B. D., and Boswell, T. (2013). Hypothalamic agouti-related protein expression is affected by both acute and chronic experience of food restriction and re-feeding in chickens. J. Neuroendocrinol. 25, 920-928.

Dunnington, E. A., and Siegel, P. B. (1984). Age and body weight at sexual maturity in female white Leghorn chickens. Poult. Sci. 63, 828-830. doi: 10.3382/ps. 0630828

Ebrey, T., and Koutalos, Y. (2001). Vertebrate photoreceptors. Prog. Retin. Eye Res. 20, 49-94.

Eitan, Y., Lipkin, E., and Soller, M. (2014). Body composition and reproductive performance at entry into lay of anno 1980 versus anno 2000 broiler breeder females under fast and slow release from feed restriction. Poult. Sci. 93, 12271235. doi: $10.3382 /$ ps.2013-03239

El Halawani, M., Silsby, J., Foster, L., Rozenboim, I., and Foster, D. (1992). Prolactin (PRL)- ovarian steroid synergism in the suppression of luteinizing hormone (LH) in the incubating turkey (Meleagris gallopavo). Poult. Sci. 71:22.

Elefteriou, F., Ahn, J., Takeda, S., Starbuck, M., Yang, X., Liu, X., et al. (2005). Leptin regulation of bone resorption by the sympathetic nervous system and CART. Nature 434, 514-520. doi: 10.1038/nature03398

Elias, C. F., Lee, C., Kelly, J., Aschkenasi, C., Ahima, R. S., Couceyro, P. R., et al. (1998). Leptin activates hypothalamic CART neurons projecting to the spinal cord. Neuron 21, 1375-1385. doi: 10.1016/s0896-6273(00)80656-x

Etches, R. J. (1996). Reproduction in Poultry. Wallingford: CAB international.

Fang, X., Zhu, X., Chen, S., Zhang, Z., Zeng, Q., Deng, L., et al. (2014). Differential gene expression pattern in hypothalamus of chickens during fasting-induced 
metabolic reprogramming : functions of glucose and lipid metabolism in the feed intake of chickens. Poult. Sci. 93, 2841-2854. doi: 10.3382/ps.2014-04047

Fatemi, S. A., Mehrabani-Yegnaneh, H., Nejati-Javaremi, A., and Niknafs, S. (2012). Association of neuropeptide $Y$ and gonadotrophin-releasing hormone receptor gene SNPs with breeding value for growth and egg production traits in Mazandaran native chickens. Genet. Mol. Res. 11, 2539-2547. doi: 10.4238/ 2012.july.10.9

Foster, R. G., and Follett, B. K. (1985). The involvement of a rhodopsin-like photopigment in the photoperiodic response of the Japanese quail. J. Comp. Physiol. A 157, 519-528. doi: 10.1007/bf00615153

Foster, R. G., Follett, B. K., and Lythgoe, N. (1985). Rhodopsin-like sensitivity of extra-retinal photoreceptors mediating the photoperiodic response in quail. Nature 313, 50-52. doi: 10.1038/313050a0

Foster, R. G., Grace, M. S., Provencio, I., Degrip, W. J., and Garcia-Fernandez, J. M. (1994). Identification of vertebrate deep brain photoreceptors. Neurosci. Biobehav. Rev. 18, 541-546. doi: 10.1016/0149-7634(94)90009-4

Foster, R. G., and Helfrich-Förster, C. (2001). The regulation of circadian clocks by light in fruitflies and mice. Philos. Trans. R. Soc. B Biol. Sci. 356, 1779-1789. doi: 10.1098/rstb.2001.0962

Foster, R. G., Korf, H. W., and Schalken, J. J. (1987). Immunocytochemical markers revealing retinal and pineal but not hypothalamic photoreceptor systems in the Japanese quail. Cell Tissue Res. 248, 161-167. doi: 10.1007/bf01239977

Fraley, G. S., Coombs, E., Gerometta, E., Colton, S., Sharp, P. J., Li, Q., et al. (2013). Distribution and sequence of gonadotropin-inhibitory hormone and its potential role as a molecular link between feeding and reproductive systems in the Pekin duck (Anas platyrhynchos domestica). Gen. Comp. Endocrinol. 184, 103-110. doi: 10.1016/j.ygcen.2012.11.026

Fraley, G. S., and Kuenzel, W. J. (1993). Precocious puberty in chicks (Gallus Domesticus) induced by central injections of neuropeptidue Y. Life Sci. 52, 1649-1656. doi: 10.1016/0024-3205(93)90047-7

Freedman, M. S., Lucas, R. J., Soni, B., von Schantz, M., Munoz, M., David-Gray, Z., et al. (1999). Circadian behavior by non-rod, non-cone, ocular photoreceptors. Science 284, 502-504. doi: 10.1126/science.284.5413.502

Frisch, R. E., and McArthur, J. W. (1974). Menstrual cycles: fatness as a determinant of minimum weight for height necessary for their maintenance or onset. Am. Assoc. Adv. Sci. 185, 949-951. doi: 10.1126/science.185.4155.949

Fruebis, J., Tsao, T.-S., Javorschi, S., Ebbets-Reed, D., Erickson, M. R. S., and Yen, F. T. (2001). Proteolytic cleavage product of $30-\mathrm{kDa}$ adipocyte complementrelated protein increases fatty acid oxidation in muscle and causes weight loss in mice. Proc. Natl. Acad. Sci. U.S.A. 98, 2005-2010. doi: 10.1073/pnas.98.4.2005

García-Fernández, J. M., Cernuda-cernuda, R., Davies, W. I. L., Rodgers, J., Turton, M., Peirson, S. N., et al. (2015). The hypothalamic photoreceptors regulating seasonal reproduction in birds : a prime role for VA opsin. Front. Neuroendocrinol. 37, 13-28. doi: 10.1016/j.yfrne.2014.11.001

Gautvik, K. M., de Lecea, L., Gautvik, V. T., Danielson, P. E., Tranque, P., and Dopazo, A. (1996). Overview of the most prevalent hypothalamus-specific mRNAs, as identified by directional tag PCR subtraction. Proc. Natl. Acad. Sci. U.S.A. 93, 8733-8738. doi: 10.1073/pnas.93.16.8733

Gehlert, D. R. (1999). Role of hypothalamic neuropeptide Y in feeding and obesity. Neuropeptides 33, 329-338. doi: 10.1054/npep.1999.0057

Gerets, H. H. J., Peeters, K., Arckens, L., Vandesande, F., and Berghman, L. R. (2000). Sequence and distribution of pro-opiomelanocortin in the pituitary and the brain of the chicken (Gallus gallus). J. Comp. Neurol. 417, 250-262. doi: 10.1002/(sici)1096-9861(20000207)417:2<250::aid-cne9>3.0.co;2-z

German, J., Kim, F., Schwartz, G. J., Havel, P. J., Rhodes, C. J., Schwartz, M. W., et al. (2009). Hypothalamic leptin signaling regulates hepatic insulin sensitivity via a neurocircuit involving the vagus nerve. Endocrinology 150, 4502-4511. doi: 10.1210/en.2009-0445

Grandhaye, J., Lecompte, F., Staub, C., Venturi, E., Plotton, I., Cailleau-Audouin, E., et al. (2019). Assessment of the body development kinetic of broiler breeders by non-invasive imaging tools. Poult. Sci. 98, 4140-4152. doi: 10.3382/ps/ pez112

Guillaume, J. (1976). The dwarfing gene dw: its effects on anatomy, physiology, nutrition, management. Its Application in Poultry Industry. Worlds Poult. Sci. J. 32, 285-305. doi: 10.1079/wps19760009

Guillod-Maximin, E., Roy, A. F., Vacher, C. M., Aubourg, A., Bailleux, V., and Lorsignol, A. (2009). Adiponectin receptors are expressed in hypothalamus and colocalized with proopiomelanocortin and neuropeptide $\mathrm{Y}$ in rodent arcuate neurons. J. Endocrinol. 200, 93-105. doi: 10.1677/joe-08-0348

Hadley, J., Ocón-Grove, O. M., and Ramachandran, R. (2020). Adiponectin is secreted by theca layer cells isolated from chicken ovarian follicles. Reproduction 159, 275-288. doi: 10.1530/rep-19-0505

Hahn, T. M., Breininger, J. F., Baskin, D. G., and Schwartz, M. W. (1998). Coexpression of Agrp and NPY in fasting-activated hypothalamic neurons. Nat. Neurosci. 1, 271-272. doi: 10.1038/1082

Halford, S., Pires, S. S., Turton, M., Davies, W. L., Zheng, L., Gonza, I., et al. (2009). VA opsin-based photoreceptors in the hypothalamus of birds. Curr. Biol. 19, 1396-1402. doi: 10.1016/j.cub.2009.06.066

Hankins, M. W., Davies, W. L., and Foster, R. G. (2008a). "The evolution of nonvisual photopigments in the central nervous system of vertebrates," in Evolution of Visual and Non-Visual Pigments, eds D. M. Hunt, M. W. Hankins, S. P. Collin, and N. J. Marshall (Boston, MA: Springer).

Hankins, M. W., Peirson, S. N., and Foster, R. G. (2008b). Melanopsin: an exciting photopigment. Trends Neurosci. 31, 27-36. doi: 10.1016/j.tins.2007.1 1.002

Hanon, E. A., Lincoln, G. A., Fustin, J. M., Dardente, H., Masson-Pévet, M., Morgan, P. J., et al. (2008). Ancestral TSH mechanism signals summer in a photoperiodic mammal. Curr. Biol. 18, 1147-1152. doi: 10.1016/j.cub.2008.0 6.076

Harrold, J. A., Williams, G., and Widdowson, P. S. (1999). Changes in hypothalamic agouti-related protein (AGRP), but not $\alpha$-MSH or pro-opiomelanocortin concentrations in dietary-obese and food-restricted rats. Biochem. Biophys. Res. Commun. 258, 574-577. doi: 10.1006/bbrc. 1999.0675

Hart, N. S. (2001). The visual ecology of avian photoreceptors. Prog. Retin. Eye Res. 20, 675-703. doi: 10.1016/s1350-9462(01)00009-x

Harvey, S., Scanes, C. G., Chadwick, A., and Bolton, W. (1979a). Growth hormone and prolactin secretion in growing domestic fowl influence of sex and breed. $B r$. Poult. Sci. 29, 9-17. doi: 10.1080/00071667908416544

Harvey, S., Scanes, C. G., Chadwick, A., Knight, P. J., and Callard, I. P. (1978). Effect of growth hormone and oestradiol on vitellogenesis in hypophysectomised pigeons. IRCS Med. Sci. 6:198.

Harvey, S., Scanes, C. G., and Sharp, P. J. (1979b). Variations in plasma growth hormone concentrations in laying hens. Br. Poult. Sci. 20, 163-166. doi: 10. 1080/00071667908416564

Hazlerigg, D., and Loudon, A. (2008). New insights into ancient seasonal life timers. Curr. Biol. 18, 795-804.

Hen, G., Yosefi, S., Simchaev, V., Shinder, D., Hruby, V. J., and FriedmanEinat, M. (2006). The melanocortin circuit in obese and lean strains of chicks. J. Endocrinol. 190, 527-535. doi: 10.1677/joe.1.06783

Hendricks, G. L., Hadley, J. A., Krzysik-Walker, S. M., Prabhu, K. S., Vasilatos-Younken, R., and Ramachandran, R. (2009). Unique profile of chicken adiponectin, a predominantly heavy molecular weight multimer, and relationship to visceral adiposity. Endocrinology 150, 3092-3100. doi: 10.1210/ en.2008- 1558

Higgins, S. E., Ellestad, L. E., Trakooljul, N., McCarthy, F., Saliba, J., Cogburn, L. A., et al. (2010). Transcriptional and pathway analysis in the hypothalamus of newly hatched chicks during fasting and delayed feeding. BMC Genomics 11:162. doi: 10.1186/1471-2164-11-162

Hill, J. W., Elmquist, J. K., and Elias, C. F. (2008). Hypothalamic pathways linking energy balance and reproduction. Am. J. Physiol. Metab. 294, E827-E832.

Hojo, M., Takada, I., Kimura, W., Fukuda, K., and Yasugi, S. (2006). Expression patterns of the chicken peroxisome proliferator-activated receptors (PPARs) during the development of the digestive organs. Gene Expr. Patterns 6, 171-179. doi: 10.1016/j.modgep.2005.06.009

Holthues, H., Engel, L., Spessert, R., and Vollrath, L. (2005). Circadian gene expression patterns of melanopsin and pinopsin in the chick pineal gland. Biochem. Biophys. Res. Commun. 326, 160-165. doi: 10.1016/j.bbrc.2004.11.022

Homma, K., Sakakibara, Y., and Ohta, M. (1994). "Potential sites and action spectra for encephalic photoreception in the Japanese quail," in Proceedings of the First International Symposium on Avian Endocrinology, ed. B. K. Follett (Bangor: University College of North Wales), 25-26.

Honda, K., Kamisoyama, H., Saneyasu, T., Sugahara, K., and Hasegawa, S. (2007). Central administration of insulin suppresses food intake in chicks. Neurosci. Lett. 423, 153-157. doi: 10.1016/j.neulet.2007.07.004 
Hrabia, A. (2015). Growth hormone production and role in the reproductive system of female chicken. Gen. Comp. Endocrinol. 220, 112-118. doi: 10.1016/ j.ygcen.2014.12.022

Hrabia, A., Paczoska-Eliasiewicz, H. E., Berghman, L. R., Harvey, S., and Rząsa, J. (2008). Expression and localization of growth hormone and its receptors in the chicken ovary during sexual maturation. Cell Tissue Res. 332, 317-328. doi: 10.1007/s00441-008-0595-7

Hrabia, A., Sechman, A., Gertler, A., and Rząsa, J. (2011). Effect of growth hormone on steroid content, proliferation and apoptosis in the chicken ovary during sexual maturation. Cell Tissue Res. 345, 191-202. doi: 10.1007/s00441-0111187-5

Hrabia, A., Sechman, A., and Rzasa, J. (2012). Independent, Non-IGF-1 mediated, $\mathrm{GH}$ action on estradiol secretion by prehierarchical ovarian follicles in chicken. In vitro study. Folia Biol. 60, 235-241.

Hrabia, A., Sechman, A., and Rzasa, J. (2014). Effect of growth hormone on basal and LH-stimulated steroid secretion by chicken yellow ovarian follicles. An in vitro study. Folia Biol. 62, 135-142.

Hull, K. L., Fraser, R. A., Marsh, J. A., and Harvey, S. (1993). Growth hormone receptor gene expression in sex-linked dwarf Leghorn chickens: evidence against a gene deletion. J. Endocrinol. 137, 91-98. doi: 10.1677/joe.0.1370091

Hull, K. L., Marsh, J. A., and Harvey, S. (1999). A missense mutation in the GHR gene of Cornell sex-linked dwarf chickens does not abolish serum GH binding. J. Endocrinol. 161, 495-501. doi: 10.1677/joe.0.1610495

Huo, L., Gmaber, K., Greeley, S., Silva, J., Huntoon, N., Leng, X., et al. (2009). Leptin-dependent control of glucose balance and locomotor activity by POMC neurons. Cell Metab. 9, 537-547. doi: 10.1016/j.cmet.2009.0 5.003

Ikemoto, T., and Park, M. K. (2005). Chicken RFamide-related peptide (GnIH) and two distinct receptor subtypes: identification, molecular characterization, and evolutionary considerations. J. Reprod. Dev. 51, 359-377. doi: 10.1262/jrd. 16087

Jaccoby, S., Arnon, E., Snapir, N., and Robinzon, B. (1995). Effects of estradiol and tamoxifen on feeding, fattiness, and some endocrine criteria in hypothalamic obese hens. Pharmacol. Biochem. Behav. 50, 55-63. doi: 10.1016/0091-3057(94) 00251-d

Johnson, A. L., and Bridgham, J. T. (2001). Regulation of steroidogenic acute regulatory protein and luteinizing hormone receptor messenger ribonucleic acid in hen granulosa cells. Endocrinology 142, 3116-3124. doi: 10.1210/endo. 142.7.8240

Johnson, A. L., and Woods, D. C. (2009a). Dynamics of avian ovarian follicle development: cellular mechanisms of granulosa cell differentiation. Gen. Comp. Endocrinol. 163, 12-17. doi: 10.1016/j.ygcen.2008.11.012

Johnson, A. L., and Woods, D. C. (2009b). "Ovarian dynamics and follicle development," in Reproductive Biology and Phylogeny of Birds, ed. B. G. M. Jamieson (Enfield, NH: Science Publishers), 243-278.

Joseph, N. T., Morgan, K., Sellar, R., McBride, D., Millar, R. P., and Dunn, I. C. (2009). The chicken type III GnRH receptor homologue is predominantly expressed in the pituitary, and exhibits similar ligand selectivity to the type I receptor. J. Endocrinol. 202, 179-190. doi: 10.1677/joe-08-0544

Juss, T., Meddle, S., Servant, R., and King, V. (1993). Melatonin and photoperiodic time measurement in Japanese quail (Coturnix coturnix japonica). Proc. R. Soc. Long B 254, 21-28. doi: 10.1098/rspb.1993.0121

Ka, S., Lindberg, J., Strömstedt, L., Fitzsimmons, C., Lindqvist, N., and Lundeberg, J. (2009). Extremely different behaviours in high and low body weight lines of chicken are associated with differential expression of genes involved in neuronal plasticity. J. Neuroendocrinol. 21, 208-216. doi: 10.1111/j.1365-2826. 2009.01819.x

Kadowaki, T., and Yamauchi, T. (2005). Adiponectin and adiponectin receptors. Endocr. Rev. 26, 439-451. doi: 10.1210/er.2005-0005

Kalra, P. S., Dube, M. G., Xu, B., and Kalra, S. P. (1997). Increased receptor sensitivity to neuropeptide $\mathrm{Y}$ in the hypothalamus may underlie transient hyperphagia and body weight gain. Regul. Pept. 72, 121-130. doi: 10.1016/ s0167-0115(97)01045-8

Kameda, Y., Miura, M., and Nishimaki, T. (2001). Localization of neuropeptide $\mathrm{Y}$ mRNA and peptide in the chicken hypothalamus and their alterations after food deprivation, dehydration, and castration. J. Comp. Neurol. 436, 376-388. doi: $10.1002 / \mathrm{cne} .1074$
Kamohara, S., Burcelin, R., Halaas, J. L., Friedman, J. M., and Charron, M. J. (1997). Acute stimulation of glucose metabolism in mice by leptin treatment. Nature 389, 374-377.

Kang, S., Leclerc, B., Kosonsiriluk, S., Mauro, L., Iwasawa, A., and Halawani, M. E. E. L. (2010). Melanopsin expression in dopamine-melatonin neurons of the premammillary nucleus of the hypothalamus and season reproduction in birds. Neuroscience 170, 200-213. doi: 10.1016/j.neuroscience.2010.0 6.082

Kang, S. W., and Kuenzel, W. J. (2015). Deep-brain photoreceptors (DBPs) involved in the photoperiodic gonadal response in an avian species, Gallus gallus. Gen. Comp. Endocrinol. 211, 106-113. doi: 10.1016/j.ygcen.2014.11.020

Kang, S. W., Thayananuphat, A., Rozenboim, I., Millam, J. R., Proudman, J. A., and El Halawani, M. E. (2006). Expression of hypothalamic GnRH-I mRNA in the female turkey at different reproductive states and following photostimulation. Gen. Comp. Endocrinol. 146, 91-99. doi: 10.1016/j.ygcen.2005.10.017

Kato, M., Sugiyama, T., Sakai, K., Yamashita, T., Fujita, H., and Sato, K. (2016). Two Opsin 3-related proteins in the chicken retina and brain : a TMT-Type Opsin 3 is a blue-light sensor in retinal horizontal cells, hypothalamus, and cerebellum. PLoS One 18:e0163925. doi: 10.1371/journal.pone.0163925

Kawakami, S. I., Bungo, T., Ando, R., Ohgushi, A., Shimojo, M., Masuda, Y., et al. (2000). Central administration of $\alpha$-melanocyte stimulating hormone inhibits fasting- and neuropeptide Y-induced feeding in neonatal chicks. Eur. J. Pharmacol. 398, 361-364. doi: 10.1016/s0014-2999(00)00344-7

Kershaw, E. E., and Flier, J. S. (2004). Adipose tissue as an endocrine organ. J. Clin. Endocrinol. Metab. 89, 2548-2556.

Kobayashi, Y., Jimenez-Krassel, F., Li, Q., Yao, J., Huang, R., and Ireland, J. J. (2004). Evidence that cocaine- and amphetamine-regulated transcript is a novel intraovarian regulator of follicular atresia. Endocrinology 145, 5373-5383. doi: 10.1210/en.2004-0283

Koike, T. I., Shimada, K., and Cornett, L. E. (1988). Plasma levels of immunoreactive mesotocin and vasotocin during oviposition in chickens: relationship to oxytocic action of the peptides in vitro and peptide interaction with myometrial membrane binding sites. Gen. Comp. Endocrinol. 70, 119-126. doi: 10.1016/0016-6480(88)90100-1

Kosonsiriluk, S., Mauro, L. J., Chaiworakul, V., Chaiseha, Y., and El Halawani, M. E. (2012). Photoreceptive oscillators within neurons of the premammillary nucleus (PMM) and seasonal reproduction in temperate zone birds. Gen. Comp. Endocrinol. 190, 149-155. doi: 10.1016/j.ygcen.2013.02.015

Koylu, E. O., Balkan, B., Kuhar, M. J., and Pogun, S. (2006). Cocaine and amphetamine regulated transcript (CART) and the stress response. Peptides 27, 1956-1969. doi: 10.1016/j.peptides.2006.03.032

Kristensen, P., Judge, M. E., Thim, L., Ribel, U., Christjansen, K. N., Wulff, B. S., et al. (1998). Regulated by leptin. Nature 393, 72-76.

Kuenzel, W. J. (2000). Central nervous system regulation of gonadal development in the avian male. Poult. Sci. 79, 1679-1688. doi: 10.1093/ps/79.11.1679

Kuenzel, W. J., Douglass, L. W., and Davison, B. A. (1987). Robust feeding following central administration of neuropeptide Y or peptide YY in chicks, Gallus domesticus. Peptides 8, 823-828. doi: 10.1016/0196-9781(87)90066-0

Kuenzel, W. J., Kang, S. W., and Zhou, Z. J. (2015). Exploring avian deep-brain photoreceptors and their role in activating the neuroendocrine regulation of gonadal development. Poult. Sci. 94, 786-798. doi: 10.3382/ps.2014-04370

Kumar, V., Singh, B. P., and Rani, S. (2004). The bird clock: a complex, multioscillatory and highly diversified system. Biol. Rhythm Res. 35, 121-144. doi: 10.1080/09291010412331313287

Larkina, T. A., Sazanova, A. L., Fomichev, K. A., Barkova, O. Y., Malewski, T., Jaszczak, K., et al. (2011). HMG1A and PPARG are differently expressed in the liver of fat and lean broilers. J. Appl. Genet. 52, 225-228. doi: 10.1007/s13353010-0023-z

Lebedeva, I. Y., Lebedev, V. A., Grossmann, R., Kuzmina, T. I., and Parvizi, N. (2004). Characterization of growth hormone binding sites in granulosa and theca layers at different stages of follicular maturation and ovulatory cycle in the domestic hen. Biol. Reprod. 71, 1174-1181. doi: 10.1095/biolreprod.104.030056

Lebrethon, M. C., Vandersmissen, E., Gérard, A., Parent, A. S., and Bourguignon, J. P. (2000). Cocaine and amphetamine-regulated-transcript peptide mediation of leptin stimulatory effect on the rat gonadotropin-releasing hormone pulse generator in vitro. J. Neuroendocrinol. 12, 383-385. doi: 10.1046/j.1365-2826. 2000.00497.x 
Ledoux, S., Campos, D. B., Lopes, F. L., Dobias-Goff, M., Palin, M. F., and Murphy, B. D. (2006). Adiponectin induces periovulatory changes in ovarian follicular cells. Endocrinology 147, 5178-5186. doi: 10.1210/en.2006-0679

Lee, B. K., Kim, J. S., Ahn, H. J., Hwang, J. H., Kim, J. M., Lee, H. T., et al. (2010). Changes in hepatic lipid parameters and hepatic messenger ribonucleic acid expression following estradiol administration in laying hens (Gallus domesticus). Poult. Sci. 89, 2660-2667. doi: 10.3382/ps.2010-00686

Lei, L., and Lixian, Z. (2012). Effect of $24 \mathrm{~h}$ fasting on gene expression of AMPK, appetite regulation peptides and lipometabolism related factors in the hypothalamus of broiler chicks. Asian Australas. J. Anim. Sci. 25, 1300-1308. doi: 10.5713/ajas.2012.12153

Leslie, R. A., Sanders, S. J. K., Anderson, S. I., Schuhler, S., Horan, T. L., and Ebling, F. J. P. (2001). Appositions between cocaine and amphetamine-related transcript- and gonadotropin releasing hormone-immunoreactive neurons in the hypothalamus of the Siberian hamster. Neurosci. Lett. 314, 111-114. doi: 10.1016/s0304-3940(01)02291-1

Li, C., Chen, P., and Smith, M. S. (2000). Corticotropin releasing hormone neurons in the paraventricular nucleus are direct targets for neuropeptide $\mathrm{Y}$ neurons in the arcuate nucleus: an anterograde tracing study. Brain Res. 854, 122-129. doi: 10.1016/s0006-8993(99)02324-0

Li, H. F., Zhu, W. Q., Chen, K. W., Wu, X., Tang, Q. P., Gao, Y. S., et al. (2009). Polymorphism in NPY and IGF-I genes associate with reproductive traits in Wenchang chicken. Afr. J. Biotechnol. 8, 4744-4748.

Li, P., Yu, X., Xie, J., Yao, X., Liu, W., Yao, J., et al. (2017). Expression of cocaineand amphetamine-regulated transcript (CART) in hen ovary. Biol. Res. 50:18.

Ling, M. K., Hotta, E., Kilianova, Z., Haitina, T., Ringholm, A., and Johansson, L. (2004). The melanocortin receptor subtypes in chicken have high preference to ACTH-derived peptides. Br. J. Pharmacol. 143, 626-637. doi: 10.1038/sj.bjp. 0705900

Liu, X., Dunn, I. C., Sharp, P. J., and Boswell, T. (2007). Molecular cloning and tissue distribution of a short form chicken leptin receptor mRNA. Domest. Anim. Endocrinol. 32, 155-166. doi: 10.1016/j.domaniend.2006.02.001

Luquet, S., Lopez-Soriano, J., Holst, D., Gaudel, C., Jehl-Pietri, C., Fredenrich, A., et al. (2004). Roles of peroxisome proliferator-activated receptor delta (PPAR $\delta$ ) in the control of fatty acid catabolism. A new target for the treatment of metabolic syndrome. Biochimie 86, 833-837. doi: 10.1016/j.biochi.2004.09.024

Maclusky, N. J., Naftolin, F., and Leranthl, C. (1988). Immunocytochemical evidence for direct synaptic connections between corticotrophin-releasing factor (CRF) and gonadotrophin-releasing hormone (GnRH)- containing neurons in the preoptic area of the rat. Brain Res. 439, 391-395. doi: 10.1016/ 0006-8993(88)91501-6

Maddineni, S., Metzger, S., Oco, O., Hendricks, G., and Ramachandran, R. (2005). Adiponectin gene is expressed in multiple tissues in the chicken: food deprivation influences adiponectin. Endocrinology 146, 4250-4256. doi: 10. 1210/en.2005-0254

Maddineni, S., Ocon-Grove, O., Krzysik-Walker, S., Hendricks, G., and Ramachandran, R. (2008). Gonadotropin-inhibitory hormone (GnIH) receptor gene is expressed in the chicken ovary: potential role of $\mathrm{GnIH}$ in follicular maturation. Reproduction 135, 267-274. doi: 10.1530/rep-07-0369

Mangelsdorf, D. J., Thummel, C., Beato, M., Herrlich, P., Schiitq, G., Umesono, K., et al. (1995). The nuclear receptor superfamily: the second decade. Cell 83, 835-839. doi: 10.1016/0092-8674(95)90199-x

Mantzoros, C., Petridou, E., Dessypris, N., Chavelas, C., Dalamaga, M., Alexe, D. M., et al. (2004). Adiponectin and breast cancer risk. J. Clin. Endocrinol. Metab. 89, 1102-1107.

Matsuo, H., Baba, Y., Arimura, A., and Schally, A. (1971). Structure of the porcine LH- and FSH-releasing hormone. I. The proposed amino acid sequence. Biochem. Biophys. Res. Commun. 43, 1334-1339. doi: 10.1016/s0006-291x(71) 80019-0

McConn, B., Wang, G., Yi, J., Gilbert, E. R., Osugi, T., and Ubuka, T. (2014). Gonadotropin-inhibitory hormone-stimulation of food intake is mediated by hypothalamic effects in chicks. Neuropeptides 48, 327-334. doi: 10.1016/j.npep. 2014.09.001

Menaker, M. (1968). Extraretinal light perception in the sparrow, I. Entrainment of the biological clock. Proc. Natl. Acad. Sci. U.S.A. 59, 414-421. doi: 10.1073/ pnas.59.2.414

Meng, B., Cao, Z., Gai, Y., Liu, M., Gao, M., and Chen, M. (2019). Effects of recombinant goose adiponectin on steroid hormone secretion in Huoyan geese ovarian granulosa cells. Anim. Reprod. Sci. 205, 34-43. doi: 10.1016/j. anireprosci.2019.03.019

Meng, H., Li, H., Zhao, J. G., and Gu, Z. L. (2005). Differential expression of peroxisome proliferator-activated receptors alpha and gamma gene in various chicken tissues. Domest. Anim. Endocrinol. 28, 105-110. doi: 10.1016/j. domaniend.2004.05.003

Mizuno, T. M., and Mobbs, C. (1999). Hypothalamic agouti-related protein messenger ribonucleic acid is inhibited by leptin and stimulated by fasting. Endocrinology 140, 814-817. doi: 10.1210/endo.140.2.6491

Mountjoy, K. G., Mortrud, M. T., Low, M. J., Simerly, R. B., and Cone, R. D. (1994). Localization of the melanocortin-4 receptor (MC4-R) in neuroendocrine and autonomic control circuits in the brain. Mol. Endocrinol. 8, 1298-1308. doi: $10.1210 /$ me.8.10.1298

Mrosovsky, N. (1990). Rheostasis: The Physiology of Change. New York, NY: Oxford University Press.

Muller, B. K. R., Cox, R. F., and Carey, N. H. (1970). Effects of progesterone on protein metabolism in chicken oviduct tissue pretreated with oestrogen. Biochem. J. 120, 337-344. doi: 10.1042/bj1200337

Nagamori, K., Ishibashi, M., Shiraishi, T., Oomura, Y., and Sasaki, K. (2003). Effects of leptin on hypothalamic arcuate neurons in Wistar and Zucker rats: an in vitro study. Exp. Biol. Med. 228, 1162-1167. doi: 10.1177/153537020322801010

Nakane, Y., Shimmura, T., Abe, H., and Yoshimura, T. (2014). ntrinsic photosensitivity of a deep brain photoreceptor. Curr. Biol. 24, R596-R597.

Nakane, Y., and Yoshimura, T. (2010). Deep brain photoreceptors and a seasonal signal transduction cascade in birds. Cell Tissue Res. 342, 341-344. doi: 10.1007/ s00441-010-1073-6

Nakao, N., Ono, H., Yamamura, T., Anraku, T., Takagi, T., Higashi, K., et al. (2008). Thyrotrophin in the pars tuberalis triggers photoperiodic response. Nature 452, 317-322. doi: 10.1038/nature06738

Ni, Y., Lu, L., Chen, J., and Zhao, R. (2011). Changes of hypothalamic GnRH-I, POMC and NPY mRNA expression and serum IGF-I and leptin concentrations during maturation of shaoxing ducks (Anas platyrhynchos). Asian Australas. J. Anim. Sci. 24, 1211-1216. doi: 10.5713/ajas.2011.11024

Ni, Y., Lv, J., Wang, S., and Zhao, R. (2013). Sexual maturation in hens is not associated with increases in serum leptin and the expression of leptin receptor mRNA in hypothalamus. J. Anim. Sci. Biotechnol. 4:24. doi: 10.1186/20491891-4-24

Nilsson, L., Binart, N., Bohlooly, M., Bramnert, M., Egecioglu, E., Kindblom, J., et al. (2005). Prolactin and growth hormone reulate adiponectin secretion and receptor expression in adipose tissue. Biochem. Biophys. Res. Commun. 331, 1120-1126. doi: 10.1016/j.bbrc.2005.04.026

Ohuchi, H., Yamashita, T., Tomonari, S., Fujita-Yanagibayashi, S., Sakai, K., Noji, S., et al. (2012). A non-mammalian type opsin 5 functions dually in the photoreceptive and non-photoreceptive organs of birds. PLoS One 7:e31534. doi: 10.1371/journal.pone.0031534

Ojano-Dirain, C., Toyomizu, M., Wing, T., Cooper, M., and Bottje, W. G. (2007). Gene expression in breast muscle and duodenum from low and high feed efficient broilers. Poult. Sci. 86, 372-381. doi: 10.1093/ps/86.2.372

Okano, T., Yoshlzawa, T., and Fukada, Y. (1994). Pinopsin is a chicken pineal photoreceptive molecule. Nature 372, 94-97. doi: 10.1038/372094a0

Olofsson, L. E., Pierce, A. A., and Xu, A. W. (2009). Functional requirement of AgRP and NPY neurons in ovarian cycle-dependent regulation of food intake. Proc. Natl. Acad. Sci. U.S.A. 106, 15932-15937. doi: 10.1073/pnas.090474 7106

Paczoska-Eliasiewicz, H., Gertler, A., Proszkowiec, M., Proudman, J., Hrabia, A., Sechman, A., et al. (2003). Attenuation by leptin of the effects of fasting on ovarian function in hens (Gallus domesticus). Reproduction 126, 739-751. doi: 10.1530/reprod/126.6.739

Paczoska-Eliasiewicz, H. E., Proszkowiec-Weglarz, M., Proudman, J., Jacek, T., Mika, M., and Sechman, A. (2006). Exogenous leptin advances puberty in domestic hen. Domest. Anim. Endocrinol. 31, 211-226. doi: 10.1016/j. domaniend.2005.10.005

Palmer, S. S., and Bahr, J. M. (1992). Follicle stimulating hormone increases serum oestradiol-17 beta concentrations, number of growing follicles and yolk deposition in aging hens (Gallus gallus domesticus) with decreased egg production. Br. Poult. Sci. 33, 403-414. doi: 10.1080/00071669208417478

Peirson, S., and Foster, R. G. (2006). Melanopsin: Another way of signaling light. Neuron 49, 331-339. doi: 10.1016/j.neuron.2006.01.006 
Perry, G. C. (1995). "Lighting," in Welfare in the Laying Hen (Wallingford: CAB International), 299-311.

Perttula, J., and Bédécarrats, G. Y. (2012). Blindness in smoky joe roosters results in advanced sexual maturation. Can. J. Anim. Sci. 92, 483-491. doi: 10.4141/ cjas2012-053

Phillips-Singh, D., Li, Q., Takeuchi, S., Ohkubo, T., Sharp, P., and Boswell, T. (2003). Fasting differentially regulates expression of agouti-related peptide, pro-opiomelanocortin, prepro-orexin, and vasoactive intestinal polypeptide mRNAs in the hypothalamus of Japanese quail. Cell Tissue Res. 313, 217-225. doi: $10.1007 / \mathrm{s} 00441-003-0755-8$

Porte, D., Baskin, D. G., and Schwartz, M. W. (2002). Leptin and insulin action in the central nervous system. Nutr. Rev. 60, S20-S29.

Pralong, F. P. (2010). Insulin and NPY pathways, and the control of GnRH function, and puberty onset. Mol. Cell. Endocrinol. 324, 82-86. doi: 10.1016/ j.mce.2010.01.037

Prescott, N. B., and Wathes, C. M. (1999). Spectral sensitivity of the domestic fowl (Gallus g. domesticus). Br. Poult. Sci. 40, 332-339. doi: 10.1080/00071669987412

Prevot, V., Croix, D., Bouret, S., Dutoit, S., Tramu, G., Stefano, G. B., et al. (1999). Definitive evidence for the existence of morphological plasticity in the external zone of the median eminence during the rat estrous cycle: Implication of neuro-glio-endothelial interactions in gonadotropin-releasing hormone release. Neuroscience 94, 809-819. doi: 10.1016/s0306-4522(99) 00383-8

Prokop, J. W., Schmidt, C., Gasper, D., Duff, R. J., Milsted, A., Ohkubo, T., et al. (2014). Discovery of the elusive leptin in birds: identification of several 'Missing Links' in the evolution of leptin and its receptor. PLoS One 9:e92751. doi: 10.1371/journal.pone.0092751

Provencio, I., Jiang, G., De Grip, W. J., Hayes, W. P., and Rollag, M. D. (1998). Melanopsin: an opsin in melanophores, brain, and eye. Proc. Natl. Acad. Sci. U.S.A. 95, 340-345. doi: 10.1073/pnas.95.1.340

Ramachandran, R., Ocon-Grove, O., and Metzger, S. L. (2007). Molecular cloning and tissue expression of chicken AdipoR1 and AdipoR2 complementary deoxyribonucleic acids. Domest. Anim. Endocrinol. 33, 19-31. doi: 10.1016/j. domaniend.2006.04.004

Ramesh, R., Kuenzel, W., Buntin, J., and Proudman, J. A. (2000). Identification of growth-hormone- and prolactin-containing neurons within the avian brain. Cell Tissue Res. 299, 371-383. doi: 10.1007/s004410050035

Ramesh, R., Proudman, J. A., and Kuenzel, W. J. (1996). Changes in pituitary somatotroph and lactotroph distribution in laying and incubating turkey hens. Gen. Comp. Endocrinol. 104, 67-75. doi: 10.1006/gcen.1996.0142

Rancourt, R. C., Schellong, K., Ott, R., Bogatyrev, S., Tzschentke, B., and Plagemann, A. (2015). Acquired alterations of hypothalamic gene expression of insulin and leptin receptors and glucose transporters in prenatally high-glucose exposed three-week old chickens do not coincide with aberrant promoter DNA methylation. PLoS One 10:e0119213. doi: 10.1371/journal.pone.0119213

Rastogi, A., Kumari, Y., Rani, S., and Kumar, V. (2013). Neural correlates of migration: activation of hypothalamic clock(s) in and out of migratory state in the blackheaded bunting (Emberiza melanocephala). PLoS One 8:e70065. doi: 10.1371/journal.pone.0070065

Rehder, N. B., Bird, D. M., and Laguë, P. C. (1986). Variations in plasma corticosterone, estrone, estradiol-17 $\beta$, and progesterone concentrations with forced renesting, molt, and body weight of captive female American kestrels. Gen. Comp. Endocrinol. 62, 386-393. doi: 10.1016/0016-6480(86)90048-1

Ren, J., Li, Y., Xu, N., Li, H., Li, C., Han, R., et al. (2017). Association of estradiol on expression of melanocortin receptors and their accessory proteins in the liver of chicken (Gallus gallus). Gen. Comp. Endocrinol. 240, 182-190. doi: 10.1016/j.ygcen.2016.10.012

Render, C., Hull, K., and Harvey, S. (1995). Neural expression of the pituitary GH gene. J. Endocrinol. 147, 413-422. doi: 10.1677/joe.0.1470413

Resnyk, C. W., Carré, W., Wang, X., Porter, T. E., Simon, J., and Bihan-duval, E. (2013). Transcriptional analysis of abdominal fat in genetically fat and lean chickens reveals adipokines, lipogenic genes and a link between hemostasis and leanness. BMC Genomics 14:557. doi: 10.1186/1471-2164-14-557

Richardson, R. D., Boswell, T., Raffety, B. D., Seeley, R. J., Wingfield, J. C., and Woods, S. C. (1995). NPY increases food intake in white-crowned sparrows: effect in short and long photoperiods. Am. J. Physiol. Regul. Integr. Comp. Physiol. 268, R1418-R1422.
Robinson, F. E., and Etches, R. J. (1986). Ovarian steroidogenesis during follicular maturation in the domestic fowl (Gallus domesticus). Biol. Reprod. 35, 10961105. doi: 10.1095/biolreprod35.5.1096

Robinson, F. E., Etches, R. J., Anderson-Langmuir, C. E., Burke, W. H., Cheng, K. W., and Cunningham, F. J. (1988). Steroidogenic relationships of gonadotrophin hormones in the ovary of the hen (Gallus domesticus). Gen. Comp. Endocrinol. 69, 455-466. doi: 10.1016/0016-6480(88)90038-x

Robinson, F. E., Fasenko, G. M., and Renema, R. A. (2003). Optimizing Chick Production in Broiler Breeders. Edmonton: Spotted Cow Press, 1-24.

Rogge, G., Jones, D., Hubert, G. W., Lin, Y., and Kuhar, M. J. (2008). CART peptides: regulators of body weight, reward and other functions. Nat. Rev. Neurosci. 9, 747-758. doi: 10.1038/nrn2493

Ronnekleiv, O., Ojeda, S., and Mccann, S. M. (1978). Undernutrition, puberty and the development of estrogen positive feedback female rat. Biol. Reprod. 19, 414-424. doi: 10.1095/biolreprod19.2.414

Rowan, W. (1931). The Riddle of Migration. Baltimore, MD: The Williams and Wilkins Company.

Rzasa, J. (1978). Effects of arginine vasotocin and prostaglandin E1 on the hen uterus. Prostaglandins 16, 357-372. doi: 10.1016/0090-6980(78)90215-0

Rzasa, J. (1984). The effect of arginine vasotocin on prostaglandin production of the hen uterus. Gen. Comp. Endocrinol. 53, 260-263. doi: 10.1016/0016-6480(84) 90251-x

Sagae, S. C., Menezes, E. F., Bonfleur, M. L., Vanzela, E. C., Zacharias, P., and Lubaczeuski, C. (2012). Early onset of obesity induces reproductive deficits in female rats. Physiol. Behav. 105, 1104-1111. doi: 10.1016/j.physbeh.2011.12.002

Sakurai, H., Kawashima, M., Kamiyoshi, M., and Tanaka, K. (1986). Effect of serotonin and $\beta$-endorphin on the release of luteinizing hormone in the hen (Gallus domesticus). Gen. Comp. Endocrinol. 63, 24-30. doi: 10.1016/00166480(86) $90177-2$

Saldanha, C., Deviche, P., and Silver, R. (1994). Increased VIP and decreaed GnRH expression in photorefractory dark-eyed Juncos (Junco hyemalis). General 93, 128-136. doi: 10.1006/gcen.1994.1015

Satake, H., Hisada, M., Kawada, H., Minakata, K., Ukena, K., and Tsutsui, K. (2001). Characterization of a cDNA encoding a novel avian hypothalamic neuropeptide exerting an inhibitory effect on gonadotropin release. Biochem. J. 354, 379-385. doi: $10.1042 / \mathrm{bj} 3540379$

Sato, K., Abe, H., Kono, T., Yamazaki, M., Nakashima, K., Kamada, T., et al. (2009). Changes in peroxisome proliferator-activated receptor gamma gene expression of chicken abdominal adipose tissue with different age, sex and genotype. Anim. Sci. J. 80, 322-327. doi: 10.1111/j.1740-0929.2009.00639.x

Sato, K., Fukao, K., Seki, Y., and Akiba, Y. (2004). Expression of the chicken peroxisome proliferator-activated receptor-gamma gene is influenced by aging. Nutrition, and agonist administration. Poult. Sci. 83, 1342-1347. doi: 10.1093/ ps/83.8.1342

Scanes, C. G., Sharp, P. J., Harvey, S., Godden, P. M., Chadwick, A., and Newcomer, W. S. (1979). Variations in plasma prolactin, thyroid hormones, gonadal steroids and growth hormone in turkeys during the induction of egg laying and moult by different photoperiods. Br. Poult. Sci. 20, 143-148. doi: 10.1080/ 00071667908416561

Schwartz, M. W., Seeley, R., Campfield, L., Burn, P., and Baskin, D. G. (1996). Identification of targets of leptin action in rat hypothalamus. J. Clin. Invest. 98, 1101-1106. doi: 10.1172/jcil18891

Sebag, J., Zhang, C., Hinkle, P., and Bradshaw, A. (2013). Developmental control of the melanocortin-4 receptor by MRAP2 proteins in zebrafish. Science 341, 225-240.

Sen, A., Bettegowda, A., Jimenez-Krassel, F., Ireland, J. J., and Smith, G. W. (2007). Cocaine- and amphetamine-regulated transcript regulation of follicle-stimulating hormone signal transduction in bovine granulosa cells. Endocrinology 148, 4400-4410. doi: 10.1210/en.2007-0332

Sen, A., Lv, L., Bello, N., Ireland, J. J., and Smith, G. W. (2008). Cocaineand amphetamine-regulated transcript accelerates termination of folliclestimulating hormone-induced extracellularly regulated kinase $1 / 2$ and Akt activation by regulating the expression and degradation of specific mitogenactivated protein kinase. Mol. Endocrinol. 22, 2655-2676. doi: 10.1210/me. 2008-0077

Seroussi, E., Cinnamon, Y., Yosefi, S., Genin, O., Smith, J. G., Rafati, N., et al. (2016). Identification of the long-sought leptin in chicken and duck: expression 
pattern of the highly GC-Rich Avian leptin Fits an Autocrine/Paracrine rather than. Endocrinology 157, 737-751. doi: 10.1210/en.2015-1634

Shahabi, N. A., Norton, H. W., and Nalbandov, A. V. (1975). Steroid levels in follicles and the plasma of hens during the ovulatory cycle. Endocrinology 96, 962-968. doi: 10.1210/endo-96-4-962

Sharp, P. (1993). Photoperiodic control of reproduction in the domestic hen. Poult. Sci. 72, 897-905. doi: 10.3382/ps.0720897

Sharp, P. J. (2005). Photoperiodic regulation of seasonal breeding in birds. Ann. N. Y. Acad. Sci. 1040, 189-199. doi: 10.1196/annals.1327.024

Sharp, P. J., Scanes, C. G., Williams, J. B., Harvey, S., and Chadwick, A. (1979). Variations in concentrations of prolactin, luteinizing hormone, growth hormone and progesterone in the plasma of broody bantams (Gallus domesticus). J. Endocrinol. 80, 51-57. doi: 10.1677/joe.0.080 0051

Sharp, P. J., Sterling, R. J., Talbot, R. T., and Huskisson, N. S. (1989). The role of hypothalamic vasoactive intestinal polypeptide in the maintenance of prolactin secretion in incubating bantam hens: observations using passive immunization, radioimmunoassay and immunohistochemistry. J. Endocrinol. 122, 5-13.

Sharp, P. J., Talbot, R. T., Main, G. M., Dunn, I. C., Fraser, H. M., and Huskisson, N. S. (1990). Physiological roles of chicken LHRH-I and -II in the control of gonadotropin release in the domestic chicken. J. Endocrinol. 124, 291-299. doi: $10.1677 /$ joe. 0.1240291

Shi, Z. D., Shao, X. B., Chen, N., Yu, Y. C., Bi, Y. Z., Liang, S. D., et al. (2006). Effects of immunisation against leptin on feed intake, weight gain, fat deposition and laying performance in chickens. Br. Poult. Sci. 47, 88-94. doi: 10.1080/ 00071660500475319

Shimizu, M., and Bedecarrats, G. (2006). Identification of a novel pituitary-specific chicken gonadotropin-releasing hormone receptor and its splice variants. Biol. Reprod. 75, 800-808. doi: 10.1095/biolreprod.105.050252

Shimizu, M., and Bédécarrats, G. Y. (2010). Activation of the chicken gonadotropin-inhibitory hormone receptor reduces gonadotropin releasing hormone receptor signaling. Gen. Comp. Endocrinol. 167, 331-337. doi: 10. 1016/j.ygcen.2010.03.029

Shipp, S. L., Cline, M. A., and Gilbert, E. R. (2016). Recent advances in the understanding of how neuropeptide $\mathrm{Y}$ and $\alpha$-melanocyte stimulating hormone function in adipose physiology a -melanocyte stimulating hormone function in adipose physiology. Adipocyte 5, 333-350. doi: 10.1080/21623945.2016. 1208867

Shiraishi, J., Yanagita, K., Fujita, M., and Bungo, T. (2008). Central insulin suppresses feeding behavior via melanocortins in chicks. Domest. Anim. Endocrinol. 34, 223-228. doi: 10.1016/j.domaniend.2007.05.002

Shodono, M., Nakamura, T., Tanabe, Y., and Wakabayashi, K. (1975). Simultaneous determination of oestradiol-17beta, progesterone, and luteinizing hormone in the plasma during the ovulatory cycle of the hen. Acta Endocrinol. 78, 565-573. doi: 10.1530/acta.0.0780565

Siegel, P. B., and Dunnington, E. A. (2017). "Reproductive complications associated with selection for broiler growth," in Poultry Genetics and Breeding, eds W. G. Hill, J. M. Manson, and D. Hewitt (Edinburgh: British Poultry Science Ltd), 59-71.

Silver, R., Witkovsky, P., Horvath, P., Alones, V., Barnstable, C. J., and Lehman, M. N. (1988). Coexpression of opsin- and VIP-like-immunoreactivity in CSFcontacting neurons of the avian brain. Cell Tissue Res. 253, 189-198.

Sims, W., Yi, J., Cline, M. A., and Gilbert, E. R. (2017). Central injection of a synthetic chicken partial leptin peptide does not affect food intake in chicks. Neurosci. Lett. 656, 165-168. doi: 10.1016/j.neulet.2017.07.038

Singh, D., Kumari, Y., Rastogi, A., Rani, S., and Kumar, V. (2013). Neuropeptide y mRNA and peptide in the night-migratory redheaded bunting brain. Cell Tissue Res. 354, 551-562. doi: 10.1007/s00441-013-1667-x

Singh, O., Kumar, S., Singh, U., Kumar, V., Lechan, R. M., and Singru, P. S. (2016). Cocaine- and amphetamine-regulated transcript peptide (CART) in the brain of zebra finch, Taeniopygia guttata: organization, interaction with neuropeptide $\mathrm{Y}$, and response to changes in energy status. J. Comp. Neurol. 524, 3014-3041. doi: $10.1002 /$ cne.24004

Siopes, T. D., and Wilson, W. O. (1980). Participation of the eyes in the photostimulation of chickens. Poult. Sci. 59, 1122-1125. doi: 10.3382/ps. 0591122

Sirotkin, A. V., and Grossmann, R. (2007). Leptin directly controls proliferation, apoptosis and secretory activity of cultured chicken ovarian cells. Comp.
Biochem. Physiol. A Mol. Integr. Physiol. 148, 422-429. doi: 10.1016/j.cbpa.2007. 06.001

Song, Z., Liu, L., Yue, Y., Jiao, H., Lin, H., and Sheikhahmadi, A. (2012). Fasting alters protein expression of AMP-activated protein kinase in the hypothalamus of broiler chicks (Gallus gallus domesticus). Gen. Comp. Endocrinol. 178, 546555. doi: 10.1016/j.ygcen.2012.06.026

Soni, B. G., and Foster, R. G. (1997). A novel and ancient vertebrate opsin. FEBS Lett. 406, 279-283. doi: 10.1016/s0014-5793(97)00287-1

Soni, B. G., Philp, A. R., Foster, R. G., and Knox, B. E. (1998). Novel retinal photoreceptors [3]. Nature 394, 27-28. doi: 10.1038/27794

Stansfield, S. C., and Cunningham, F. J. (1987). Modulation by endogenous opioid peptides of the secretion of LHRH from cockerel (Gallus domesticus) mediobasal hypothalamic tissue. J. Endocrinol. 114, 103-110. doi: 10.1677/joe. 0.1140103

Sterling, R., and Sharp, P. J. (1982). The localisation of LH-RH neurones in the diencephalon of the domestic hen. Cell Tissue Res. 222, 283-298.

Stevens, L. (2007). "Avian steroid hormones and their control of gene expression," in Avian Biochemistry and Molecular Biology, ed. L. Stevens (Cambridge: Cambridge University Press), 159-176. doi: 10.1017/cbo978051152577 3.012

Stevenson, T. J., and Ball, G. F. (2012). Disruption of neuropsin mRNA expression via RNA interference facilitates the photoinduced increase in thyrotropinstimulating subunit b in birds. Eur. J. Neurosci. 36, 2859-2865. doi: 10.1111/ j.1460-9568.2012.08209.x

Strader, A. D., and Buntin, J. D. (2003). Changes in agouti-related peptide during the ring dove breeding cycle in relation to prolactin and parental hyperphagia. J. Neuroendocrinol. 15, 1046-1053. doi: 10.1046/j.1365-2826.2003.01092.x

Strader, A. D., Schiöth, H. B., and Buntin, J. D. (2003). The role of the melanocortin system and the melanocortin-4 receptor in ring dove (Streptopelia risoria) feeding behavior. Brain Res. 960, 112-121. doi: 10.1016/s0006-8993(02) 03799-x

Straus, D. S., and Glass, C. K. (2001). Cyclopentenone prostaglandins: new insights on biological activities and cellular targets. Med. Res. Rev. 21, 185-210. doi: 10.1002/med.1006

Sugawara, T., Holt, J. A., Driscoll, D., Strauss, J. F., Lin, D., Miller, W. L., et al. (1995). Human steroidogenic acute regulatory protein: functional activity in COS-1 cells, tissue-specific expression, and mapping of the structural gene to 8 p11.2 and a pseudogene to chromosome 13. Proc. Natl. Acad. Sci. U.S.A. 92, 4778-4782. doi: 10.1073/pnas.92.11.4778

Surbhi, R. A., Malik, S., Rani, S., and Kumar, V. (2016). Changes in brain peptides associated with reproduction and energy homeostasis in photosensitive and photorefractory migratory redheaded buntings. Gen. Comp. Endocrinol. 230231, 67-75. doi: 10.1016/j.ygcen.2016.03.031

Surbhi, R. A., Rani, S., and Kumar, V. (2015). Seasonal plasticity in the peptide neuronal systems: Potential roles of gonadotrophin-releasing hormone, gonadotrophin-inhibiting hormone, neuropeptide $\mathrm{Y}$ and vasoactive intestinal peptide in the regulation of the reproductive axis in subtropical indian we. J. Neuroendocrinol. 27, 357-369. doi: 10.1111/jne.12274

Tachibana, T., Oikawa, D., Takahashi, H., Boswell, T., and Furuse, M. (2007). The anorexic effect of alpha-melanocyte-stimulating hormone is mediated by corticotrophin-releasing factor in chicks. Comp. Biochem. Physiol. Part A 147, 173-178. doi: 10.1016/j.cbpa.2006.12.044

Tachibana, T., Sato, M., Takahashi, H., Ukena, K., Tsutsui, K., and Furuse, M. (2005). Gonadotropin-inhibiting hormone stimulates feeding behavior in chicks. Brain Res. 1050, 94-100. doi: 10.1016/j.brainres.2005.05.035

Tachibana, T., Takagi, T., Tomonaga, S., Ohgushi, A., Ando, R., Denbow, D., et al. (2003). Central administration of cocaine- and amphetamine-regulated transcript inhibits food intake in chicks. Neurosci. Lett. 337, 131-134. doi: 10.1016/s0304-3940(02)01321-6

Tahmoorespur, M., Ghazanfari, S., and Nobari, K. (2010). Evaluation of adiponectin gene expression in the abdominal adipose tissue of broiler chickens: feed restriction, dietary energy, and protein influences adiponectin messenger ribonucleic acid expression. Poult. Sci. 89, 2092-2100. doi: 10.3382/ps.201000772

Takahashi, K. A., and Cone, R. D. (2005). Fasting induces a large, leptin-dependent increase in the intrinsic action potential frequency of orexigenic arcuate nucleus neuropeptide Y/Agouti-related protein neurons. Endocrinology 146, 1043-1047. doi: 10.1210/en.2004-1397 
Takeda, M., and Ohkubo, T. (2019). Identification of hypothalamic genes in associating with food intake during incubation behavior in domestic chicken. Anim. Sci. J. 90, 1293-1302. doi: 10.1111/asj.13261

Takeuchi, S., Kudo, T., and Takahashi, S. (1998). Molecular cloning of the chicken melanocortin 2 (ACTH)-receptor gene. Biochim. Biophys. Acta 1403, 102-108. doi: 10.1016/s0167-4889(98)00022-6

Takeuchi, S., Suzuki, H., Hirose, S., Yabuuchi, M., Sato, C., Yamamoto, H., et al. (1996). Molecular cloning and sequence analysis of the chick melanocortin 1-receptor gene. Biochim. Biophys. Acta 1306, 122-126. doi: 10.1016/01674781(96)00026-7

Takeuchi, S., and Takahashi, S. (1998). Melanocortin receptor genes in the chicken - Tissue distributions. Gen. Comp. Endocrinol. 112, 220-231. doi: 10.1006/gcen. 1998.7167

Takeuchi, S., and Takahashi, S. (1999). A possible involvement of melanocortin 3 receptor in the regulation of adrenal gland function in the chicken. Biochim. Biophys. Acta 1448, 512-518. doi: 10.1016/s0167-4889(98)00165-7

Takeuchi, S., Teshigawara, K., and Takahashi, S. (1999). Molecular cloning and characterization of the chicken pro-opiomelanocortin (POMC) gene. Biochim. Biophys. Acta 1450, 452-459. doi: 10.1016/s0167-4889(99)00046-4

Takeuchi, S., Teshigawara, K., and Takahashi, S. (2000). Widespread expression of Agouti-related protein (AGRP) in the chicken: a possible involvement of AGRP in regulating peripheral melanocortin systems in the chicken. Biochim. Biophys. Acta 1496, 261-269. doi: 10.1016/s0167-4889(00)00022-7

Taouis, M., Chen, J. W., Daviaud, C., Dupont, J., Derouet, M., and Simon, J. (1998). Cloning the chicken leptin gene. Gene 208, 239-242. doi: 10.1016/ s0378-1119(97)00670-7

Tartaglia, L. A. (1997). The leptin receptor. J. Biol. Chem. 272, 6093-6096.

Tarttelin, E. E., Bellingham, J., Hankins, M. W., Foster, R. G., and Lucas, R. J. (2003). Neuropsin (Opn5): a novel opsin identified in mammalian neural tissue. FEBS Lett. 554, 410-416. doi: 10.1016/s0014-5793(03)01212-2

Teshigawara, K., Takahashi, S., Boswell, T., Li, Q., Tanaka, S., and Takeuchi, S. (2001). Identification of avian $\alpha$-melanocyte-stimulating hormone in the eye: temporal and spatial regulation of expression in the developing chicken. J. Endocrinol. 168, 527-537. doi: 10.1677/joe.0.1680527

Tomonari, S., Takagi, A., Akamatsu, S., Noji, S., and Ohuchi, H. (2005). A non-canonical photopigment, melanopsin, is expressed in the differentiating ganglion, horizontal, and bipolar cells of the chicken retina. Dev. Dyn. 234, 783-790. doi: 10.1002/dvdy.20600

Tosca, L., Crochet, S., Ferré, P., Foufelle, F., Tesseraud, S., and Dupont, J. (2006). AMP-activated protein kinase activation modulates progesterone secretion in granulosa cells from hen preovulatory follicles. J. Endocrinol. 190, 85-97. doi: 10.1677/joe.1.06828

True, C., Verma, S., Grove, K. L., and Smith, M. S. (2013). Cocaine- and amphetamine-regulated transcript is a potent stimulator of gnrh and kisspeptin cells and may contribute to negative energy balance-induced reproductive inhibition in females. Endocrinology 154, 2821-2832. doi: 10.1210/en.20131156

Tsutsui, K., Saigoh, E., Ukena, K., Teranishi, H., Fujisawa, Y., Kikuchi, M., et al. (2000). A novel avian hypothalamic peptide inhibiting gonadotropin release. Biochem. Biophys. Res. Commun. 275, 661-667. doi: 10.1006/bbrc.2000.3350

Ubuka, T., Bentley, G. E., Ukena, K., and Tsutsui, K. (2005). Melatonin induces the expression of gonadotropin-inhibitory hormone in the avian brain. Proc. Natl. Acad. Sci. U.S.A. 102, 3052-3057. doi: 10.1073/pnas.0403840102

Ubuka, T., Ukena, K., Sharp, P. J., Bentley, G. E., and Tsutsui, K. (2006). Gonadotropin-inhibitory hormone inhibits gonadal development and maintenance by decreasing gonadotropin synthesis and release in male quail. Endocrinology 147, 1187-1194. doi: 10.1210/en.2005-1178

Underwood, H., Binkley, S., Siopes, T., and Mosher, K. (1984). Melatonin rhythms in the eyes, pineal bodies, and blood of Japanese Quail (Coturnix coturnix japonica). Gen. Comp. Endocrinol. 56, 70-81. doi: 10.1016/0016-6480(84) 90063-7

Van Anes, P., Janssens, W., Onagbesan, O. M., Bruggeman, V., Buys, N., Sanders, J., et al. (2010). Quantification of growth hormone receptor extra- and intracellular domain gene expression in chicken liver by quantitative competitive RT-PCR. Gen. Comp. Endocrinol. 122, 213-224. doi: 10.1006/gcen.2001.7632

van der Klein, S. A. S., Bédécarrats, G. Y., Robinson, F. E., and Zuidhof, M. J. (2018). Early photostimulation at the recommended body weight reduced broiler breeder performance. Poult. Sci. 97, 3736-3745. doi: 10.3382/ps/pey215 van der Klein, S. A. S., Zuidhof, M. J., and Bédécarrats, G. Y. (2020). Diurnal and seasonal dynamics affecting egg production in meat chickens: a review of mechanisms associated with reproductive dysregulation. Anim. Reprod. Sci. 213:106257. doi: 10.1016/j.anireprosci.2019.106257

van Sambeek, F. (2010). Longer production cycles from a genetic perspective. Prog. Layer Genet. 10, 1-5.

Walzem, R. L., and Chen, S. (2014). Obesity-induced dysfunctions in female reproduction: lessons from birds and mammals. Adv. Nutr. 5, 199-206. doi: 10.3945/an.113.004747

Walzem, R. L., Hansen, R. J., Williams, D. L., and Hamilton, R. L. (1999). Estrogen induction of VLDLy assembly in egg-laying hens. J. Nutr. 129, 467-472.

Wang, H., Jiang, R., He, Q., Zhang, Y., Zhang, Y., Li, Y., et al. (2012). Expression pattern of peroxisome proliferator-activated receptors in rat hippocampus following cerebral ischemia and reperfusion injury. PPAR Res. 2012:596394.

Wang, Y., Mu, Y., Li, H., Ding, N., Wang, Q., Wang, Y., et al. (2008). Peroxisome proliferator-activated receptor- $\gamma$ gene: a key regulator of adipocyte differentiation in chickens. Poult. Sci. 87, 226-232. doi: 10.3382/ps.2007-00329

Whetham, E. (1933). Factors modifying egg production with special reference to seasonal changes. J. Agric. Sci. 23, 383-418. doi: 10.1017/s002185960005 3284

Williams, J., Sharp, P. J., and Goddard, C. (1992). The effect of growth hormone on ovarian follicular growth in the domestic hen. J. Reprod. Fertil. 9:59.

Williams, K. W., Scott, M. M., and Elmquist, J. K. (2009). From observation to experimentation: leptin action in the mediobasal hypothalamus. Am. J. Clin. Nutr. 89, 985-990.

Wilson, B., and Bagnol, D. (1999). Physiological and anatomical circuitry between Agouti-related protein and leptin signaling. Endocrinology 140, 2387-2397. doi: 10.1210/endo.140.5.6728

Wu, C., Lv, C., Wan, Y., Li, X., Zhang, J., Li, J., et al. (2019). Arginine vasotocin (AVT)/mesotocin (MT) receptors in chickens: evidence for the possible involvement of AVT-AVPR1 signaling in the regulation of oviposition and pituitary prolactin expression. Gen. Comp. Endocrinol. 281, 91-104. doi: 10.1016/j.ygcen.2019.05.013

Wu, X., Li, H., Yan, M., Tang, Q., Chen, K., and Wang, J. (2007). Associations of Gonadotropin-Releasing Hormone Receptor (GnIHR) and Neuropeptide Y (NPY) Genes' polymorphosms with egg-laying traits in Wenchang chicken. Agric. Sci. China 6, 499-504. doi: 10.1016/s1671-2927(07)60075-3

Yamamura, T., Hirunagi, K., Ebihara, S., and Yoshimura, T. (2004). Seasonal morphological changes in the neuro-glial interaction between gonadotropinreleasing hormone nerve terminals and glial endfeet in Japanese quail. Endocrinology 145, 4264-4267. doi: 10.1210/en.2004-0366

Yamamura, T., Yasuo, S., Hirunagi, K., Ebihara, S., and Yoshimura, T. (2006). T3 implantation mimics photoperiodically reduced encasement of nerve terminals by glial processes in the median eminence of Japanese quail. Cell Tissue Res. 324, 175-179. doi: 10.1007/s00441-005-0126-8

Yamashita, T., Ohuchi, H., Tomonari, S., Ikeda, K., Sakai, K., and Shichida, Y. (2010). Opn5 is a UV-sensitive bistable pigment that couples with Gi subtype of G protein. Proc. Natl. Acad. Sci. U.S.A. 107, 22084-22089. doi: 10.1073/pnas. 1012498107

Yamauchi, T., Kamon, J., Ito, Y., Tsuchida, A., Yokomizok, T., Kita, S., et al. (2003). Cloning of adiponectin receptors that mediate antidiabetic metabolic effects. Nature 423, 762-769. doi: 10.1038/nature01705

Yamauchi, T., Kamon, J., Minokoshi, Y., Ito, Y., Waki, H., Uchida, S., et al. (2002). Adiponectin stimulates glucose utilization and fatty-acid oxidation by activating AMP-activated protein kinase. Nat. Med. 8, 1288-1295. doi: 10.1038/ $\mathrm{nm} 788$

Yamauchi, T., Kamon, J., Waki, H., Terauchi, Y., Kubota, N., Hara, K., et al. (2001). The fat-derived hormone adiponectin reverses insulin resistance associated with both lipoatrophy and obesity. Nat. Med. 7, 941-946. doi: 10.1038/90984

Yang, S., Suh, Y., Choi, Y. M., Shin, S., Han, J. Y., and Lee, K. (2013). Loss of fat with increased adipose triglyceride lipase-mediated lipolysis in adipose tissue during laying stages in quail. Lipids 48, 13-21. doi: 10.1007/s11745-012-3742-6

Yasuo, S., Watanabe, M., Nakao, N., Takagi, T., Follett, B. K., Ebihara, S., et al. (2005). The reciprocal switching of two thyroid hormone-activating and inactivating enzyme genes is involved in the photoperiodic gonadal response of Japanese quail. Endocrinology 146, 2551-2554. doi: 10.1210/en.2005-0057

Yasuo, S., Watanabe, M., Okabayashi, N., Ebihara, S., and Yoshimura, T. (2003). Circadian clock genes and photoperiodism: comprehensive analysis of 
clock gene expression in the Mediobasal Hypothalamus, the Suprachiasmatic Nucleus, and the Pineal Gland of Japanese Quail under Various Light Schedules. Endocrinology 144, 3742-3748. doi: 10.1210/en.2003-0435

Yau, K. W. (1994). Phototransduction mechanism in retinal rods and cones. Investig. Ophthalmol. Vis. Sci. 35, 9-32.

Yi, J., Gilbert, E. R., Siegel, P. B., and Cline, M. A. (2015). Fed and fasted chicks from lines divergently selected for low or high body weight have differential hypothalamic appetite-associated factor mRNA expression profiles. Behav. Brain Res. 286, 58-63. doi: 10.1016/j.bbr.2015.02.008

Yosefi, S., Hen, G., Rosenblum, C. I., Cerasale, D. J., Beaulieu, M., Criscuoloand, F., et al. (2010). Lack of leptin activity in blood samples of Adélie penguin, and bar-tailed godwit. J. Endocrinol. 207, 113-122. doi: 10.1677/joe-10-0177

Yoshimura, T. (2013). Thyroid hormone and seasonal regulation of reproduction. Front. Neuroendocrinol. 34, 157-166. doi: 10.1016/j.yfrne.2013.04.002

Yoshimura, T., Yasuo, S., Watanabe, M., Iigo, M., Yamamura, T., Hirunagi, K., et al. (2003). Light-induced hormone conversion of T4 to T3 regulates photoperiodic response of gonads in birds. Nat. Lett. 426, 178-181. doi: 10.1038/nature02117

Yoshizawa, T. (1992). The road to color vision: structure, evolution and function of chicken and gecko visual pigments. Photochem. Photobiol. 56, 859-867. doi: 10.1111/j.1751-1097.1992.tb09707.x

Young, J. Z. (1962). The Life of Vertebrates. Oxford: The Clarendon Press.

Yuan, L., Wang, Y., Hu, Y., and Zhao, R. (2017). In ovo leptin administration modulates glucocorticoid receptor mRNA expression specifically in the hypothalamus of broiler chickens. Neurosci. Lett. 638, 181-188. doi: 10.1016/j. neulet.2016.12.020

Zelenka, D. J., Jones, D. E., Dunnington, E. A., and Siegel, P. B. (1987). Selection for body weight at eight weeks of age. 18. Comparisons between mature and immature pullets at the same live weight and age. Poult. Sci. 66, 41-46.

Zhang, J., Li, X., Zhou, Y., Cui, L., Li, J., and Wu, C. (2017). The interaction of MC3R and MC4R with MRAP2, ACTH, $\alpha-\mathrm{MSH}$ and AgRP in chickens. J. Endocrinol. 234, 155-174. doi: 10.1530/joe-17-0131
Zhang, W., Bai, S., Liu, D., Cline, M. A., and Gilbert, E. R. (2015). Neuropeptide $\mathrm{Y}$ promotes adipogenesis in chicken adipose cells in vitro. Comp. Biochem. Physiol. Part A Mol. Integr. Physiol. 181, 62-70. doi: 10.1016/j.cbpa.2014.1 1.012

Zhang, W., Sumners, L. H., Siegel, P. B., Cline, M. A., and Gilbert, E. R. (2013). Quantity of glucose transporter and appetite-associated factor mRNA in various tissues after insulin injection in chickens selected for low or high body weight. Physiol. Genomics 45, 1084-1094. doi: 10.1152/physiolgenomics.00102 .2013

Zhang, X. Y., Wu, M. Q., Wang, S. Z., Zhang, H., Du, Z. Q., and Li, Y. M. (2018). Genetic selection on abdominal fat content alters the reproductive performance of broilers. Animal 12, 1232-1241. doi: 10.1017/s175173111700 2658

Zuidhof, M., Schneider, B., Carney, V., Korver, D., and Robinson, F. (2014). Growth, efficiency, and yield of commercial broilers from 1957, 1978, and 2005. Poult. Sci. 93, 2970-2982. doi: 10.3382/ps.2014-0 4291

Zuidhof, M. J. (2018). Lifetime productivity of conventionally and precision-fed broiler breeders. Poult. Sci. 97, 3921-3937. doi: 10.3382/ps/pey252

Conflict of Interest: The authors declare that the research was conducted in the absence of any commercial or financial relationships that could be construed as a potential conflict of interest.

Copyright (c) 2020 Hanlon, Ramachandran, Zuidhof and Bédécarrats. This is an open-access article distributed under the terms of the Creative Commons Attribution License (CC BY). The use, distribution or reproduction in other forums is permitted, provided the original author(s) and the copyright owner(s) are credited and that the original publication in this journal is cited, in accordance with accepted academic practice. No use, distribution or reproduction is permitted which does not comply with these terms. 